\title{
Meta-analysis of genes in commercially available nutrigenomic tests denotes lack of association with dietary intake and nutrient-related pathologies
}

\author{
Cristiana Pavlidis ${ }^{1}$, Zoi Lanara ${ }^{1,2}$, Angeliki Balasopoulou ${ }^{1}$, Jean-Christophe Nebel ${ }^{3}$, \\ Theodora Katsila ${ }^{1}$, George P. Patrinos ${ }^{1, *}$
}
${ }^{1}$ University of Patras, School of Health Sciences, Department of Pharmacy, Patras, Greece
${ }^{2}$ University of Trieste, Faculty of Mathematical, Physical and Natural Sciences,
Department of Biological Sciences, Trieste, Italy

3 Kingston University, Faculty of Science, Engineering and Computing, School of Computing and Information Systems, London, UK

* Corresponding author at:

University of Patras, School of Health Sciences, Department of Pharmacy,

University Campus, Rion, GR-265 04, Patras, Greece

Telephone: +30-2610962339, Fax: +30-2610969955; Email: gpatrinos@ upatras.gr 


\section{Authors email addresses:}

Cristiana Pavlidis: chpavlidou @upatras.gr

Zoi Lanara: zoi_lanara@hotmail.com

Angeliki Balasopoulou: agg_balasopoulou@hotmail.com

Jean-Christophe Nebel: J.Nebel@kingston.ac.uk

Theodora Katsila: thkatsila@upatras.gr

George P. Patrinos: gpatrinos@ upatras.gr 


\section{Abstract}

Nutrigenomics is an emerging discipline that aims to investigate how individual genetic composition correlates with dietary intake as well as how nutrition influences gene expression. Herein, the fundamental question relates to the value of nutrigenomics testing on the basis of the currently available scientific evidence. A thorough literature search has been conducted in PubMed scientific literature database for nutrigenomics research studies on 38 genes included in nutrigenomics tests provided by various private genetic testing laboratories. Data were subsequently meta-analysed to identify possible associations between the genes of interest and dietary intake and/or nutrient-related pathologies. Data analysis occurred according to four different models due to data sparsity and inconsistency. Data from 524,952 individuals (361,153 cases and 163,439 controls) in a total of 1,170 entries were obtained. Conflicting findings indicated that there was a great incompatibility regarding the associations (or their absence) identified. No specific - and statistically significant - association was identified for any of the 38 genes of interest. In those cases, where a weak association was demonstrated, evidence was based on a limited number of studies. As solid scientific evidence is currently lacking, commercially available nutrigenomics tests cannot be presently recommended. Notwithstanding, the need for a thorough and continuous nutrigenomics research is evident as it is a highly promising tool towards precision medicine.

Keywords: nutrigenomics, nutrigenomics testing, dietary intake, nutrition, genes, metaanalysis. 


\section{Introduction}

Nutrigenomics is an emerging discipline that aims to investigate how individual genetic composition correlates with dietary intake as well as how nutrition influences gene expression (Affolter et al., 2009). To this end, nutrigenomics attempts to integrate the “omics" technologies (genomics, transcriptomics, epigenomics, metabolomics) in addition to post-translational modifications (Affolter et al., 2009; Liu and Qian, 2011). Personalized (genomic) medicine exploits genomic information in the context of guiding medical decision-making, thereby allowing physicians to make assessments of disease risk and design rational evidence-based treatment regimens. For this, the unique genomic profile of an individual has to be taken into consideration alongside their clinical profile to achieve a health-oriented decision (Pavlidis et al., 2012). However, being an emerging discipline, personalized medicine has yet to attain wide applicability in modern medical practice.

Nutrigenomic testing refers to the testing of genes that relate to conditions that are influenced by nutrition. To date, nutrigenomic testing is mostly provided using the directto-consumer (DTC) business model and given the fact that there is currently very limited information on its clinical validity, it is dealt with skepticism from the scientific community (Gulisano, 2013). This situation differs from pharmacogenomics and genetic testing of single gene disorders, where genotype-phenotype correlations are well established (Patrinos et al., 2013). To date, a large number of private genetic laboratories in several countries are providing nutrigenomic testing of several genomic variants that have been shown to be related with dietary intake and nutrition-related pathologies. Considering the fact that there are often contradictory findings as to whether these genomic variants can be correlated with such pathological inherited conditions, we sought to determine which 
ones of these genomic variants can indeed be correlated with such inherited conditions and as such have a true prognostic nutrigenomic value.

Herein, a thorough literature search and meta-analysis of 38 genes analysed in commercially available nutrigenomic tests were conducted in an effort to highlight or overrule their prognostic value, questioning their use in nutrigenomic testing. In particular, we aimed to address whether: (a) these genes were indeed associated to various nutrition/food-related pathologies/diseases, (b) there were any solid clinical-evidenced guidelines on the use of the nutrigenomic tests available, (c) scientific results and indications validate the relationship between each gene or group of genes and the various nutrition/food-related diseases, and (d) the existing research literature could be used by healthcare professionals for diet/nutrition and medical testing and therapy purposes based on the results available to date.

\section{Methods}

A thorough search was conducted in the PubMed literature database for genotypephenotype correlation studies on 38 genes using the following terms: "nutrigenomics", "gene name" and "disease name" (Table 1). The 38 genes of interest were chosen following research on commercially available nutrigenomics tests and their specifics. Our meta-analysis included 1,170 entries published from 1995 to 2012. In total, 524,952 individuals (361,153 patients and 163,439 healthy individuals) from various ethnicities were considered. Related pathologies included obesity, diabetes, insulin resistance, hypertension, metabolic syndrome and gastrointestinal diseases (ulcerative colitis, crohn's disease, HP, etc.). We focused on the genes of interest and their genomic variants (SNPs, indels, etc), the number of patients (cases) and controls, the date and type of study (single- 
gene and genome-wide association study), the location and population details (e.g. gender, race/population, etc), groups' age, the phenotypic measures included, the allele and genotype frequencies as well as the overall outcome of each study. Diseases and conditions were grouped accordingly:

1. Cardiovascular Group (including ischemia and stroke)

2. Liver (hepatic) Group

3. Obesity Group

4. Metabolic syndrome, Diabetes and Insulin Resistance Group.

5. Lung and Respiratory Group

6. Cancer Group

7. Bone Disease Group

8. Lipid Group

9. Autoimmune Disease Group

10. Gastrointestinal Group

11. Anthropometry Group

12. Nephrology Group

13. Vascular Group

14. Neurology Group

15. Nutrient Group 


\section{Inflammation Group}

17. Any other condition not included above

Data analysis occurred according to four different models due to data sparsity and inconsistency (Table 2).

\section{Data mining and preprocessing}

Data mining techniques were used to automatically obtain groups of SNPs or conditions that showed similar clustering according to the available association data. For all the genomic variants considered, the nature of their link with a condition was qualified by qualitative terms, such as: 'yes', 'may', 'no' and 'unknown' (Table 3). Then, the data derived from all studies and for every genomic variant were combined into a single record, called the 'variant phenotypic profile'. Similarly, a 'genotype profile' was generated for each condition.

Initial examination of the phenotypic profiles revealed that they were very sparse since only a fraction of possible variant/condition associations had been reported in the literature. In addition to data sparsity, many inconsistencies between studies were observed. Since data sparsity and inconsistency are issues that cannot be ignored, they were taken into account in the design of the analysis methodology. Not only did we conduct an initial analysis attempting to identify similarities between phenotype and genotype profiles, but we also decided to reduce the impact of sparsity by performing further data exploration at a lower resolution. Although this might lead to a reduction of accuracy, manual inspection of novel patterns emerging from data mining should prevent any undesirable effect of the analysis protocol. First, we worked at the gene level: all 
studies of SNPs related to a given gene were merged into a single profile, called the 'gene phenotype'. Secondly, diseases and conditions were also grouped according to similarity for analysis purposes. A summary of the number of studies/results per model/analysis methodology is provided in Table 2 .

Whatever the type of data, phenotypic and genotypic profiles were analysed to detect similarities between them. Note that we also investigated variants/genes displaying opposite effects. As in our previous work (Lanara et al., 2013), profile comparison and grouping were performed using a state-of-the-art data-mining tool, CLUTO (Rasmussen et al., 2003). More specifically, hierarchical agglomerative clustering was carried out to produce a binary tree representing similarities between profiles and highlighting possible groupings. Finally, the most informative groups were further analysed using the STRING 9.1 (http://string-db.org) database to collect additional evidence of associations.

A comprehensive list of supplemental references supporting the meta-analysis is presented under the supplemental materials section.

\section{Results}

\section{Phenotypic Profiles}

As anticipated, phenotypic profiles proved to be very sparse: despite 153 different genomic variants and 89 conditions were considered, only 679 different associations were revealed, i.e. $5 \%$ of the possible 13,617 associations. Since most associations have not been studied, our conclusions should be considered with extra caution. Moreover, a great number of inconsistencies were identified: in regards to the entire number of studies researched, $20 \%$ of the genomic variants displayed inconsistent phenotypic profiles, 
whereas an additional $64 \%$ relied on results which have never been reproduced. Similarly, $33 \%$ of the conditions studied exhibited inconsistent results and $46 \%$ consisted of unreproduced associations. As expected, the aggregation of SNP profiles into 'gene phenotype' and grouping of diseases and conditions led to significant reductions of data sparsity from $95 \%$ to $88 \%$ and $68 \%$ 'unknown' associations, respectively, and an increase in data inconsistency (Table 4).

In the case of genomic variants with identical/similar phenotypes, our analysis revealed two IL6 variants, namely rs1800797 and rs1800796. Identical/similar phenotypes for given conditions/diseases were also obtained for the APOA1, APOA4, PON1, APOC3, MTHFR, APOA5 and CRP genes. This was not true for the phenotype profiles regarding PON1 and PON2 genes. At the gene level, new associations were obtained when the following comparisons were performed: $L I P C$ vs $L D L R$ vs $A P O E, L D L R$ vs $A P O E, L D L R$ vs $L I P C, L I P C$ vs $A P O E, U C P 3-2$ vs $U C P 2, M T H F R$ vs $M T R$ vs $M T R R$ and $L P L$ vs $A D R B 2$. Focusing on the resulting groups of conditions, only two similar conditions were obtained: (i) HMGCR (rs4704209, rs3761739, rs5909, rs3761738, rs17238540, rs10038095, rs3846663, rs2303152) was found to be related with the condition groups 4, 7 and 13 (metabolic syndrome, diabetes and insulin resistance group; bone disease group and vascular group respectively) and (ii) $L D L$ (rs6413503) and APOE (rs440446) with groups 1, 9, 17 (Cardiovascular group, autoimmune disease group and other group respectively). When genes with similar phenotypes were investigated in regards to the condition groups, we have found that all clusters associations were quite weak (two out of the 17 groups). This was the case for the $A P O A 2$ vs $A B C C 6$ vs $A P O C 4$ vs $R X R A$ vs $C U B N$ genes and may be explained by the evidence of interaction between APOA2, APOC4 and RXRA. It should be noted that the genes $F A B P 2$ vs $C Y P 7 B 1$ vs $M T P$ and the PPARA vs IL8 also showed some associations to specific groups. 


\section{Data inconsistency for all options/models of analysis}

Herein, data inconsistency was profound. In brief, incompatible data were obtained for IL6 (rs1800795 and rs1800796) as well as ADRB3 genes (when searched at the gene level and the rs4994 level). Additionally, in the case of the ADRB2 gene, 4 out of the 16 conditions were found incompatible, when we investigated ADRB2 (rs1042714) in 26 studies, while 4 out of 10 incompatible conditions in 17 studies were found for ADRB2 (rs1042713). Regarding the CETP gene, data showed 7 out of 18 incompatible conditions in the 113 studies studied. When the CETP was researched at the SNPs level (rs5882, rs708272, rs1800775), the outcome was similar. Notably, the $C R P$ gene was found in 84 studies, among which 3 out of the 20 conditions studied were found to be incompatible. This is quite a low number, which needs to be further investigated and included in future metanalyses. At the SNPs level (rs1130864), only 1 condition in the 18 studies was found to be incompatible, while $C R P$ (rs1205) has a high value and no incompatibility has been published, indicating straightforward single SNP associations. Additionally, the APOA5 gene resulted in 3 out of 10 incompatible conditions in 47 studies and in 1 out of the 7 incompatible conditions in 11 studies, when the APOA5 (rs2075291) was considered. Finally, two incompatible conditions were found in each one of the APOC3, GSTP1, LIPC, $L P L, P O N 1, T N F$ and $U C P 2$. Similar results were obtained when these conditions were investigated at the SNPs level. For the MTHFR gene, 1 out of the 14 conditions was found to be incompatible in 29 studies, which certainly requires further investigation. The SNPs of interest as well as their positive or negative association to the diseases/conditions studied is shown in Figure 1. 


\section{Non-incompatible results among the four options/models of research}

Among the genes and their respective SNPs that we investigated in the various studies considered herein, there were many conditions, which were investigated devoid of incompatible results. However, due to the small amount of studies in some cases, we suggest that these points should be investigated further in a new meta-analysis by taking into account any new genome-wide association studies (GWAS) papers to include various and numerous populations. Notably, (i) $H M G C R$, PPARA and IL8 genes (when all 3 were investigated at the gene level), (ii) $C R P$ (when considered at the SNPs level), (iii) MTRR (gene and SNPs levels), (iv) MTR (gene and SNPs levels), (v) TNF SNPs level) and (vi) IL6 genes (SNPs level) showed no incompatible results in a higher number of studies per condition (gene and/or SNPs level) ranging from 1.1 to 7 studies per condition.

Indeed, when looking at the datasets analysing the links of diseases/conditions to genes and/or SNPs, various points of interest were obtained. In the case of cardiovascular diseases/conditions we have found incompatibility among conditions and diseases such as coronary vasculopathy, hypertension, essential hypertension acute or not acute myocardial infraction, ischemic stroke and coronary heart disease. However, the incompatibility varied according to the number of total studies researched. As an example, in the case of coronary heart disease and hypertension, 1 gene out of the 2 researched was found incompatible in a total of 6 studies investigated, while in the case of essential hypertension incompatibility was found in 2 out of the 5 genes researched in the 25 studies regarding cardiovascular diseases that were investigated in our meta-analysis. In the case of gastrointestinal diseases and conditions, when 3 genes investigating celiac disease were studied in 10 studies, two of them were showed incompatible results. On the other hand, other gastrointestinal conditions such as crohn's disease, ulcerative colitis, helicobacter pylori, duodenal ulcer, esophageal cancer and its complications showed no incompatibility, however there was 
only 1 study per condition. In the case of conditions/diseases such as weight/obesity/ lipid levels and various metabolic syndrome parameters (BMI, HDL-C, weight gain, triglycerides, visceral fat, abdominal adiposity, higher value of hip circumference, higher values of HDL-C, lower waist/hip ratio, metabolic syndrome, high plasma of cholesterol were researched), similar points were addressed except for the lack of incompatibility when the metabolic syndrome and the three genes researched were considered (among the 18 studies investigated). There was also a slight difference in regards to glucose and insulin conditions/diseases (glucose/insulin/diabetes/ insulin resistance/plasma insulin levels/elevated glucose levels/ gestational diabetes mellitus and carbohydrate metabolism), where studies per gene/SNP were ranging from 1 to 2.8 . Finally, cervical cancer seems to be an emerging important result, although this is a non-nutrigenomic condition. Instead, its evaluation was encouraged, as it was investigated in many of the studies described herein. Indeed, the link to cervical cancer was investigated in two genes in 13 studies, leading to 6.5 studies per gene. This outcome should be further investigated in a meta-analysis of cancer genes. Lastly, regarding the link to SLE, there were only 1 to 1.4 studies per $\mathrm{SNP} /$ gene, indicating that further research is also needed.

\section{The outcome on the diseases/conditions studied and the resulted associations with obesity, weight gain, insulin sensitivity-resistanse, diabetes and glucose levels}

Regarding obesity, only 1 study showed a positive result when the association of the $A D R A 2 B$ gene and obesity was investigated, being however population-specific. No links were found to weight gain, while the rest of the studies focused on traits, such as CVD, hypertension, insulin secretion, type 2 diabetes, heart rate, physical activity, diet and incident diabetes, anthropometric and metabolic phenotypes, essential hypertension with or 
without type 2 diabetes mellitus, metabolic syndrome, sudden cardiac death and silent myocardial ischemia. In terms of the $A D R B 3$ gene and obesity only conflicting results were obtained, whereas only one study showing no link to obesity was obtained for $C R P$. Regarding diabetes, five studies showed positive and negative links to the disease among which one study revealed conflicting results. No link was found in the only study researching IRS - 1 and type 2 diabetes. In the case of the IL6 gene and diabetes, it seems that a positive link exists, however this refers to only three studies. In addition, only one study showed a positive association between PON1 and diabetes and ApoA1 and diabetes, whereas a negative association was revealed, when $A B C A 1$ was studied. A study for the GSTT1 and GSTM1 investigating their link to type 1 diabetes showed no association. Data on $L P L$ and $U C P 3$ imply a link to insulin sensitivity. Another study investigated the possible association between insulin resistance and APOA5 and showed no association. On the other hand, one study showed a 'small yes' association between LPL and insulin resistance and two studies a 'may' association between $U C P 2$ and $U C P 2-3$, while another study showed a positive association between $A D R B 1$ and diabetes type 2. No association was found between $A D R A 2 A$ and diabetes in one study, whereas a positive association was obtained between $A D R A 2 B$ and diabetes type 2 . Finally, only one study showed no association between the fasting glucose levels of $A D R A 2 A$ and glucose levels. Notably, there were conflicting results for the $C R P$ gene and negative association data for ILIa and IL6. Conflicting results were also obtained for SLC30A8 and TLCFL2.

\section{Gastrointestinal conditions/diseases}

Regarding the gastrointestinal conditions and diseases, one study showed conflicting results on $T N F$ and ulcerative colitis as well as a negative link between the 
latter and $H L A$. The $I L 10$ showed negative results, while for the ILI gene conflicting results were shown for Helicobacter pylori. In the case of the TNF gene, there were more negative results for Helicobacter pylori and only one study showing positive results for the $-308 A G$ genotype. No link to gastric ulcer was found among the studies considered.

\section{STRING software analysis}

When the relationships between $A D R B 1-A D R B 3$ and $A D R A 1 A-A D R A 1 B$ were investigated, a strong association was obtained. Similar findings were obtained for SOD2 and SOD3. These results were not found in our meta-analysis. In brief, the conflicting results are shown in Supplementary Figures 1-5. Additionally, the absence of statistical association between genes/SNPs and condition/diseases group is depicted in Supplementary Figure 6. Data incompatibility is summarised in Tables 3 and 4. Finally, a representation of the number of studies per genes researched for certain diseases and conditions are found in Supplementary Figures 7-21.

\section{Discussion}

The need to investigate the field of nutrigenomics via a meta-analysis approach arose since our group started noticing that extensive literature was published throughout the years regarding nutrigenomics analysis, nutrigenomics tests and gene/ variations interactions with diseases influenced by nutrition. However, research studies were so far discontinuous and thus, not many final conclusions were made for diseases/conditions and/or nutrients of interest. There were sparse results and various single referenced studies, 
assuming that certain genes/mutations were associated or not to certain diseases and conditions emerged. Finally, the lack of regulation shows that there are no specific recommendations and guidelines till now in order to apply these tests in everyday life. It seems also that health professionals, but also in some cases the general public, are not totally ready for the use of these tests or they cannot fully understand or interpret them (Pavlidis et al., 2012). The need for an enhanced education/training on this field as well as data interpretation became evident in our previous study on nutrigenomics perceptions and views in Greece (Pavlidis et al., 2012). On the other hand, extra care should be given when these tests are prescribed, as their use is not yet well defined by law and by the scientific community through clinical research.

The trend of DTC and nutrigenomics testing is becoming more known to our society. Patrinos and co-workers (2013) discussed the various categories of genetic testing, one of which includes genetic tests designed to diagnose complex health conditions (Patrinos et al., 2013). In these tests, as described, where a risk for obtaining false-positive or false negative results is high, misinterpretation could often occur. Extra care should be given as misinterpretation could lead to an increased cost of the diagnostic procedures used, which were not probably needed or have the opposite effect (Patrinos et al., 2013). In the latter case, the individual becomes less vigilant about their health. At this point, we should not forget that there are very few qualified healthcare professionals to interpret the nutrigenomics tests results to individuals from the general population. As a consequence, results may not be well perceived, understood and even be acted on. Nevertheless, there is a tendency in believing that personalised nutrition would be more helpful (Pavlidis et al., 2012; Hurliman et al., 2014).

Direct to consumer testing is defined as the sale and use of genetic testing that does not include the involvement of the health care provider (Goddard et al., 2008). Companies 
offering such tests via the Internet, pharmacies and in any other commercial way are spread worldwide and grow rapidly. An increase of DTC genetic tests from 14 to 84 instances (or 53 unique tests) was shown from a study in 2008 (Thompson et al., 2011) in only four years. Among those tests, nutrigenomics testing was also largely included.

The findings of our analysis are limited, however, there are important points highlighted which may benefit from futher investigation, when new research arises with more GWAS studies included. There were very few associations and in some cases, they were based on a few studies, such as one or two studies per gene or snp or condition. In some limited cases, we have found associations that were not expected, whereas in many cases there were conflicting results. When looking at the literature for the genes usually found in nutrigenomics testing and via various companies offering DTC genetic tests on nutrigenomics, we have noticed that, generally, no clear association was supported by the existing scientific evidence. Indeed, we have grouped the genes involved in the nutrigenomics tests analysed mainly according to diseases and conditions and not to the effect of the nutrients to a specific disease or condition (we have found very few studies on these points), as we have not found many studies on these associations. For instance, it is widely known that $\omega$-fatty acids help against the risk factors of CVD, however, we have not found many studies that investigated the role of these fatty acids according to the genomic variants carried by the individuals. It should be noted that the field of nutrigenomics is highly complex, as it relies on nutrients, conditions and diseases, medical history and also eating habits, as well as genes. Our study, to our knowledge, is one of the very few to investigate and apply a meta-analysis for thirty-eight genes usually involved in nutrigenomics from a of diseases point of view that are mainly influenced by nutrition. Today, there is a lot more to be investigated and this study sets the pace for further research on all genes involved in nutrigenomics with more GWAS studies, as these will be 
more useful by including more individuals. We have found a limited amount of GWAS through our literature search and of course, this is a starting point for the future investigation of genes involved in nutrigenomics that will help the future of designing personalised nutrition, personalised diets as well as personalised medical nutritional therapy through the effect of the nutrients, the genes and the SNPs involved. Diseases/pathologies such as obesity, diabetes, cardiovascular conditions, metabolic syndrome, gastrointestinal conditions as well as factors (weight, BMI), but also lipid levels, cholesterol and triglyceride levels, would all possibly be aided by the use of nutrigenomics, when further research is available. The research and scientific community supports that in the field of nutrigenomics more should be done in the models of applying this science for personalised nutrition (Gulisano, 2013; Ordovás Muñoz, 2013). Different types of diets, using various methods, such as the blood type and diet combination are not supported by research (Wang et al., 2014). It is true that another study focusing on the PPAR, ADRB2, ADRB3, IL6, LIPC, LEP, LEPR and UCP3 genes led to variable results, when looked at their association to obesity and the outcome of fat restricted diet (Martinez et al., 2008). Additionally, one review showed a metabolic response to omega3 fatty acid supplementation for the APOE genotype and age/gender/BMI (Thifault et al., 2013). All these results in a whole show that there is a lot yet to be researched and the field of personalised diet and nutrition is ready for more studies designed in large mixed populations in order to include all possible genetic variations and polymorphisms.

The fact that nutrigenomics is a wide field that involves genes/mutations/conditions/diseases/food/nutrients etc, does not allow in such a preliminary state to proceed to the use of nutrigenomics testing in the general public. This is also stated by the position of the American Academy of Nutrition and Dietetics in 2014 (Camp and Trujilo, 2014), which identifies the problems in applying in such an early state 
without specific research on nutrigenomics, the use of nutrigenomics testing for the treatment of diseases/conditions. In fact, this position states that mutations are only partially predictive of disease risk and shows the lack of education of the dietitians to interpret such results. Many years would be probably needed in order to have definite results clinically and scientifically proven, which will then be applied to our everyday life and the future era of personalised medicine and nutrition. It would be a great scientific progress in the clinical field if we could treat patients according to their genes, mutations and have hands-on experience of how nutrient and diet interacts with them and the person itself.

\section{Conclusions}

The present study, involving meta-analysis of over half a million cases, indicated that there are conflicting findings and a great incompatibility as far as associations between genomic variants with nutrient-relate pathologies and dietary intake are considered. In the vast majority of cases, there was no statistically significant association for any of the 38 genes of interest, whereas even in the very few cases where a weak association was found, this was based on a very limited number of studies. We feel that nutrigenomic testing should not be yet provided as a commercial service by genetic laboratories, as solid scientific evidence is currently lacking for the genomic basis of nutrient-related pathologies and phenotypes. Notwithstanding, continuous research will allow patients' treatment according to their genomic variants and their interactions with nutrients and diet. In this context, metabolomics and in particular, nutri-metabolomics data as well as multi- 
omics data integration are anticipated to play a key role (Mounayar et al., 2014; Montague et al., 2014).

\section{Acknowledgements}

This study was partly funded by a European Commission research grant (RDCONNECT; FP7-305444) to GPP and encouraged by the Genomic Medicine Alliance Public Health Genomics Working group. The authors declare that they have no competing interests. 


\section{List of Abbreviations}

- AA: advanced atherosclerosis

- AASK: African-American Study of Kidney Disease and Hypertension

- ACS: Acute Coronary Ischemia

- ACS: acute coronary syndrome (s)

- AMI: acute myocardial infarction

- BC: breast cancer

- BMD: bone mineral density

- BRCA: breast cancer risk

- CAC: carotid artery compliance

- CAGB: coronary artery bypass graft

- CAD: coronary artery disease

- CD: celiac disease

- CHD: coronary heart disease

- CHF: chronic heart failure

- CIMT: carotid intima media thickness

- CKD: chronic kidney disease

- COPD: chronic obstructive pulmonary disease

- CRC: colorectal cancer

- CRC: Colorectal Cancer

- CRI: chronic renal insufficiency

- CV: coronary vasculopathy
- CVD: cardiovascular disease

- DN: diabetic nephropathy

- DPN: diabetic polyneuropathy

- EH: essential hypertension

- ESRD: end-stage renal disease

- FCH: familial combined hypercholesterolemia

- FH: familial hypercholesterolemia

- FMD: brachial artery flow-mediated vasodilatation

- GC: gastric cancer

- GH : gestational hypertension,

- GPL: gastric pre-cancerous lesions

- HALP: Hyperalphalipoproteinemia

- HCC: hepatocellular carcinoma

- HRV: Heart rate variability

- IBD: inflammatory bowel disease

- IHD: ischemic heart disease

- IMT : carotid intima-media thickness

- IPF: Idiopathic Pulmonary Fibrosis

- IS: ischemic stroke

- MI: myocardial infraction

- MS: metabolic syndrome 
- NAFLD: Non-alcoholic fatty liver disease

- NASH: non-alcoholic steatohepatitis

- OA: osteoarthritis

- PAD: peripheral arterial disease

- PD: Parkinson's disease

- PDB : Paget's disease of bone

- PDR: proliferative diabetic retinopathy

- PE: preeclampsia

- PSA: psoriasis

- RA: rheumatoid arthritis

- RA: rheumatoid arthritis

- RCR: renal cancer risk

- tHcy : plasma homocysteine

- VAHC: Veterans Affairs Hypertension Cohort

- VTE: venus thromboembolism

- UC: ulcerative colitis 


\section{References}

Mine Y, Miyashita K, and Shahidi F (2009). Nutrigenomics and Proteomics in Health and Disease-Food Factors and Gene Interactions. (Wiley-Blackwell, IA).

Camp KM, and Trujillo E (2014). Position of the Academy of Nutrition and Dietetics: nutritional genomics. J Acad Nutr Diet 114(2), 299-312.

Goddard KA, Robitaille J, Dowling NF, Parrado AR, Fishman J, Bradley LA et al. (2008). Health-related direct-to-consumer genetic tests: a public health assessment and analysis of practices related to Internet-based tests for risk of thrombosis. Public Health Genomics 12(2), 92-104.

Gulisano M (2013). Direct-to-consumer nutrigenomic testing: is it valuable in spite of its limitations? N C Med J 74, 496-497.

Hurlimann T, Menuz V, Graham J, Robitaille J, Vohl MC, and Godard B (2014). Risks of nutrigenomics and nutrigenetics? What the scientists say. Genes Nutr 9(1), 370.

Lanara Z, Giannopoulou E, Fullen M, Kostantinopoulos E, Nebel JC, Kalofonos HP, et al. (2013) Comparative study and meta-analysis of meta-analysis studies for the correlation of genomic markers with early cancer detection. Hum Genomics 7:14.

Liu B and Qian SB (2011). Translational regulation in nutrigenomics. Adv Nutr 2, 511519.

Martinez JA, Parra MD, Santos JL, Moreno-Aliaga MJ, Marti A, and Martinez-Gonzalez MA (2008). Genotype-dependent response to energy-restricted diets in obese subjects: towards personalized nutrition. Asia Pac J Clin Nutr 17(S1), 119-122. 
Montague E, Stanberry L, Higdon R, Janko I, Lee E, Anderson N, et al. (2014) MOPED 2.5--an integrated multi-omics resource: multi-omics profiling expression database now includes transcriptomics data. OMICS 18(6): 335-343.

Mounayar R, Morzel M, Brignot H, Tremblay-Franco M, Canlet C, Lucchi G, et al. (2014) Nutri-metabolomics applied to taste perception phenotype: human subjects with high and low sensitivity to taste of fat differ in salivary response to oleic acid. OMICS 18(11): 666-672.

Ordovás Muñoz JM (2013). Predictors of obesity: the "power" of the omics. Nutr Hosp 28 (Supl. 5), 63-71.

Patrinos GP, Baker DJ, Al-Mulla F, Vasiliou V, and Cooper DN (2013). Genetic tests obtainable through pharmacies: the good, the bad, and the ugly. Hum Genomics 7, 17.

Pavlidis C, Karamitri A, Barakou A, Cooper DN, Poulas K, Topouzis S, et al. (2012). Ascertainment and critical assessment of the views of the general public and healthcare professionals on nutrigenomics in Greece. Personalized Medicine 9(2), 201-210.

Rasmussen MD, Deshpande MS, Karypis G, Johnson J, Crow JA, Retzel EF (2003). wCLUTO: a Web-enabled clustering toolkit. Plant Physiol 133(2), 510-516.

Thifault E, Cormier H, Bouchard-Mercier A, Rudkowska I, Paradis AM, Garneau V et al. (2013). Effects of age, sex, body mass index and APOE genotype on cardiovascular biomarker response to an n-3 polyunsaturated fatty acid supplementation. J Nutrigenet Nutrigenomics 6, 73-82.

Thompson JR, Attia J, and Minelli C (2011). The meta-analysis of genome-wide association studies. Brief Bioinform 12, 259-269.

Wang J, Garcia-Bailo B, Nielsen DE, and El-Sohemy A (2014) ABO genotype, 'bloodtype' diet and cardiometabolic risk factors. PLoS ONE 9(1), e84749. 


\section{Figure Legend}

\section{Figure 1.}

The positive or negative association of the SNPs of interest to diseases/conditions. Our analysis show that associations are generally unknown and when genes or SNPS are showing similar profiles those only rely on very few known associations. Note that SNPS are organised according to similarity in terms of condition associations. Rows show genes or SNPS of interest, whereas columns show conditions or condition groups. White block (or light green/red): no or unclear information regarding potential association. Green block: positive association. Red block: negative association. Shades of green and red show how strong the association is.

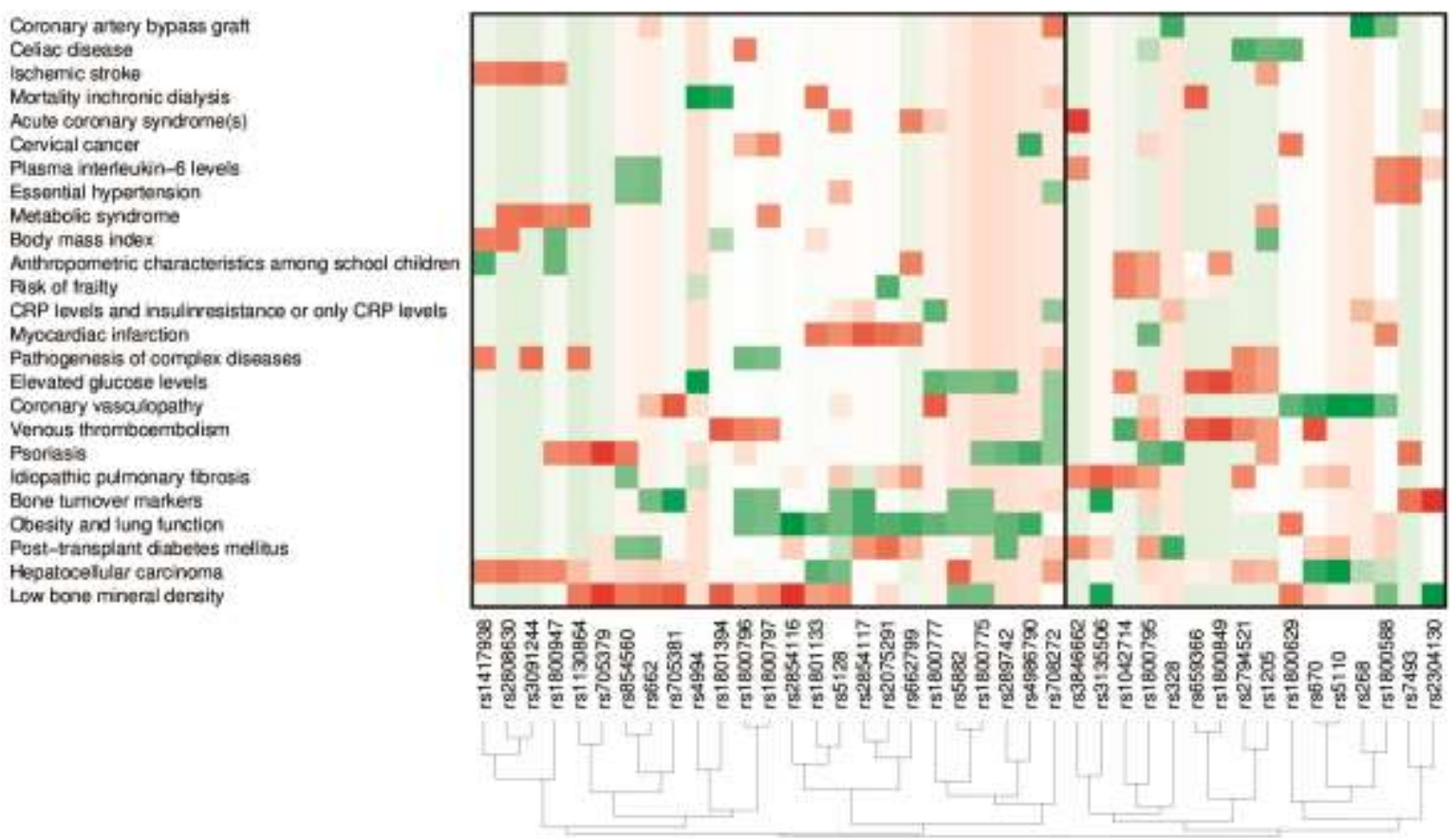


Tables 
Table 1. Search criteria for gene and disease/ pathological condition association

\begin{tabular}{|c|c|}
\hline Genes & $\begin{array}{c}\text { Disease/Pathological condition: investigation of } \\
\text { possible association }\end{array}$ \\
\hline $\begin{array}{l}\text { APOA1, } \triangle P O A 5, A P O B, \\
\text { APOC3, } А P O E\end{array}$ & $\begin{array}{l}\text { Cardiovascular disease, Coronary heart disease, } \\
\text { Coronary artery disease, Hypercholesterolemia }\end{array}$ \\
\hline CETP & $\begin{array}{l}\text { Cardiovascular disease, Coronary heart disease, } \\
\text { Coronary artery disease, Hypercholesterolemia, Diabetes }\end{array}$ \\
\hline GJA4 (CX37) & $\begin{array}{l}\text { Atherosclerosis, Hypertension, Stroke, Coronary artery } \\
\text { disease }\end{array}$ \\
\hline HMGCR & Hepatic disease, Non- alcoholic fatty liver \\
\hline LIPC & $\begin{array}{l}\text { Hepatic disease, Hypercholesterolemia, Fatty acid } \\
\text { metabolism }\end{array}$ \\
\hline LPL & Dyslipidemia, CVD, Metabolic syndrome \\
\hline PON1 & Atherosclerosis, Diabetes, Metabolic syndrome \\
\hline CAT & Diabetes, Hepatic diseases, Kidney diseases \\
\hline GPXI & Various types of gastrointestinal cancer \\
\hline GSTM1 & $\begin{array}{l}\text { Various types of gastrointestinal cancer, Various types of } \\
\text { gastrointestinal disease, Coronary artery disease }\end{array}$ \\
\hline GSTP1 & $\begin{array}{l}\text { Various types of gastrointestinal cancer, Various types of } \\
\text { gastrointestinal disease, Coronary artery disease }\end{array}$ \\
\hline GSTT1 & $\begin{array}{l}\text { Non-alcoholic fatty liver disease, Various types of } \\
\text { gastrointestinal cancer, Various types of gastrointestinal } \\
\text { disease, Coronary artery disease }\end{array}$ \\
\hline MNSOD & $\begin{array}{l}\text { Various types of gastrointestinal cancer, Coronary artery } \\
\text { disease, Various types of gastrointestinal disease }\end{array}$ \\
\hline SELS & $\begin{array}{l}\text { Diabetes, Various types of gastrointestinal disease } \\
\text { various types of gastrointestinal cancers, Metabolic risk } \\
\text { factors }\end{array}$ \\
\hline$S O D 2 \& S O D 3$ & $\begin{array}{l}\text { Coronary Artery Disease, Chronic Obstructive Pumonary } \\
\text { Disease }\end{array}$ \\
\hline EPHXI & $\begin{array}{l}\text { Chronic obstructive pulmonary disease, Various types of } \\
\text { gastrointestinal cancer, CVD, Stroke }\end{array}$ \\
\hline$U C P 2$ & Diabetes, Obesity, Abdominal obesity, Hyperinsulinemia \\
\hline$A G T$ & Coronary artery disease, Chronic kidney disease \\
\hline$C B S$ & $\begin{array}{l}\text { Celiac disease, Hyperomocystenaemia, Homocysteine } \\
\text { metabolism }\end{array}$ \\
\hline COMT & Parkinson's disease, Schizophrenia \\
\hline MTHFR & $\begin{array}{l}\text { Homocysteine metabolism, Coronary artery disease, } \\
\text { Cardiovascular disease, Coronary heart disease }\end{array}$ \\
\hline MTR & Coronary artery disease, Rheumatoid arthritis \\
\hline MTRR & $\begin{array}{l}\text { Homocysteine metabolism, Coronary artery disease, } \\
\text { Cardiovascular disease, Coronary heart disease, } \\
\text { Reuhmatoid arthritis, Folate and choline metabolism }\end{array}$ \\
\hline
\end{tabular}




\begin{tabular}{|l|l|}
\hline TCN2 & \multicolumn{1}{|c|}{$\begin{array}{c}\text { To our knowledge there were no data that could be } \\
\text { analysed at the moment that the metanalysis occured. }\end{array}$} \\
\hline $\boldsymbol{C R P}$ & $\begin{array}{l}\text { Body mass index, Obesity, Atrial fibrillation, Coronary } \\
\text { heart disease, Diabetes, Inflammation/ Inflammatory } \\
\text { response }\end{array}$ \\
\hline $\boldsymbol{I L - 6}$ & $\begin{array}{l}\text { Coronary heart disease, Inflammation/ inflammatory } \\
\text { response }\end{array}$ \\
\hline $\boldsymbol{T N F}$ & $\begin{array}{l}\text { Inflammation/Inflammatory response, Coronary artery } \\
\text { disease, Weight regain, Acute pancreatitis, Gastric cancer } \\
\text { and various types of gastrointestinal cancer }\end{array}$ \\
\hline $\boldsymbol{A D R B 2}$ & $\begin{array}{l}\text { Hypertension, Acute coronary syndrome, Obesity, } \\
\text { Cardiovascular diseases, Metabolic syndrome }\end{array}$ \\
\hline $\boldsymbol{A D R A 2 A}$ & $\begin{array}{l}\text { Ischemic stroke, Diabetes, Cardiovascular diseases, } \\
\text { Obesity, Metabolic syndrome }\end{array}$ \\
\hline $\boldsymbol{A D R B 1}$ & $\begin{array}{l}\text { Coronary heart disease, Diabetes, Obesity, Hypertension, } \\
\text { Metabolic syndrome }\end{array}$ \\
\hline $\boldsymbol{A D R A 1 B}$ & $\begin{array}{l}\text { Coronary heart disease, Diabetes, Obesity, Hypertension, } \\
\text { Metabolic syndrome }\end{array}$ \\
\hline $\boldsymbol{A D R B 3}$ & $\begin{array}{l}\text { Coronary heart disease, Diabetes, Obesity, Hypertension, } \\
\text { Metabolic syndrome }\end{array}$ \\
\hline $\boldsymbol{A D R A 1 A}$ & $\begin{array}{l}\text { Coronary heart disease, Diabetes, Obesity, Hypertension, } \\
\text { Metabolic syndrome }\end{array}$ \\
\hline
\end{tabular}


Table 2. Number of studies showing incompatibility in all four models of analysis

\begin{tabular}{|c|c|c|c|c|c|c|c|}
\hline & $\begin{array}{l}\text { model } 1 \\
\text { (conflicting } \\
\text { association } \\
\text { to } \\
\text { conditions) }\end{array}$ & $\begin{array}{l}\text { model } 1 \\
\text { (conflicting } \\
\text { association } \\
\text { to SNPs) }\end{array}$ & $\begin{array}{l}\text { model } 2 \\
\text { (conflicting gene } \\
\text { association to } \\
\text { conditions) }\end{array}$ & $\begin{array}{l}\text { model } \mathbf{2} \\
\text { (conflicting } \\
\text { association to } \\
\text { genes) }\end{array}$ & $\begin{array}{l}\text { model } 3 \\
\text { (SNPs per } \\
\text { condition } \\
\text { groups) }\end{array}$ & $\begin{array}{l}\text { model } 4 \\
\text { (conflicting gene } \\
\text { association to } \\
\text { condition groups) }\end{array}$ & $\begin{array}{l}\text { model } 4 \\
\text { (conflicting } \\
\text { association } \\
\text { to genes) }\end{array}$ \\
\hline $\begin{array}{l}\text { Incompat } \\
\text { ible } \\
\text { results }\end{array}$ & 31 & 29 & 17 & 31 & NA & 17 & 13 \\
\hline $\begin{array}{l}\text { Compatib } \\
\text { le results }\end{array}$ & 24 & 19 & 14 & 20 & NA & 13 & 3 \\
\hline $\begin{array}{l}\text { Compatib } \\
\text { le results } \\
\text { (very few } \\
\text { studies } \\
\text { per gene } \\
\text { or SNP) } \\
\end{array}$ & 98 & 41 & 14 & 9 & NA & 14 & NA \\
\hline
\end{tabular}

Please note that in option/model of analysis 3, no incompatibility was found. (NA, not available) 
Table 3. An analytical representation of the incompatible results of genes with their respective nomenclature (and the rs numbers found in the studies researched) to condition groups, * «yes» or «no»

\begin{tabular}{|c|c|c|c|c|c|}
\hline Gene & $\begin{array}{c}\text { dbSNP } \\
\text { id }\end{array}$ & $\begin{array}{l}\text { condition groups } \\
\text { with incompatible } \\
\text { results }(*)\end{array}$ & $\begin{array}{l}\text { number of } \\
\text { studied condition } \\
\text { groups }\end{array}$ & $\begin{array}{l}\text { number } \\
\text { of } \\
\text { studies }\end{array}$ & $\begin{array}{l}\begin{array}{l}\text { average number } \\
\text { of studies per } \\
\text { condition group }\end{array} \\
\end{array}$ \\
\hline IL6 & & 11 & 12 & 176 & 14.7 \\
\hline CETP & & 8 & 11 & 118 & 10.7 \\
\hline$A D R B 3$ & rs4994 & 7 & 10 & 41 & 4.1 \\
\hline$A D R B 2$ & & 5 & 9 & 54 & 6.0 \\
\hline$T N F A$ & & 5 & 9 & 65 & 7.2 \\
\hline$C R P$ & & 4 & 13 & 111 & 8.5 \\
\hline APOA5 & & 3 & 9 & 51 & 5.7 \\
\hline$L I P C$ & & 3 & 8 & 29 & 3.6 \\
\hline APOC 3 & & 2 & 9 & 34 & 3.8 \\
\hline GSTPI & rs 1695 & 2 & 4 & 12 & 3.0 \\
\hline$L P L$ & & 2 & 8 & 22 & 2.8 \\
\hline MTHFR & & 2 & 11 & 34 & 3.1 \\
\hline PON1 & & 2 & 9 & 45 & 5.0 \\
\hline$U C P 2$ & & 2 & 8 & 26 & 3.3 \\
\hline$D G K B$ & rs2191349 & 1 & 1 & 2 & 2.0 \\
\hline MTRR & rs1801394 & 1 & 9 & 15 & 1.7 \\
\hline PON2 & & 1 & 5 & 11 & 2.2 \\
\hline
\end{tabular}


Table 4. Incompatibility of condition groups in relation to the genes, * «yes» or «no».

\begin{tabular}{|c|c|c|c|c|c|}
\hline $\begin{array}{c}\text { group } \\
\text { number }\end{array}$ & group description & $\begin{array}{c}\text { genes with } \\
\text { incompatible } \\
\text { results }(*)\end{array}$ & $\begin{array}{c}\text { number } \\
\text { of } \\
\text { genes }\end{array}$ & $\begin{array}{c}\text { number } \\
\text { of } \\
\text { studies }\end{array}$ & $\begin{array}{c}\text { average } \\
\text { number of } \\
\text { studies/gene }\end{array}$ \\
\hline GROUP 1 & $\begin{array}{l}\text { Cardiovascular group } \\
\text { (including ischemia and } \\
\text { stroke) }\end{array}$ & 9 & 32 & 148 & 4.6 \\
\hline GROUP 4 & $\begin{array}{l}\text { Metabolic syndrome, } \\
\text { Diabetes and Insulin } \\
\text { Resistance group }\end{array}$ & 8 & 26 & 171 & 6.6 \\
\hline GROUP 13 & Vascular group & 7 & 15 & 76 & 5.1 \\
\hline GROUP 17 & Other' group & 7 & 18 & 73 & 4.1 \\
\hline GROUP 3 & Obesity group & 5 & 16 & 88 & 5.5 \\
\hline GROUP 6 & Cancer group & 5 & 19 & 101 & 5.3 \\
\hline GROUP 7 & Bone disease group & 5 & 28 & 155 & 5.5 \\
\hline GROUP 10 & Gastrointestinal group & 4 & 7 & 26 & 3.7 \\
\hline GROUP 5 & $\begin{array}{l}\text { Lung and Respiratory } \\
\text { group }\end{array}$ & 3 & 19 & 47 & 2.5 \\
\hline GROUP 16 & Inflammation group & 3 & 9 & 46 & 5.1 \\
\hline GROUP 8 & Lipid group & 2 & 7 & 22 & 3.1 \\
\hline GROUP 12 & Nephrology group & 2 & 6 & 23 & 3.8 \\
\hline GROUP 11 & Anthropometry group & 1 & 11 & 23 & 2.1 \\
\hline
\end{tabular}


Supplementary material 
Supplementary Information

Meta-analysis of genes in commercially available nutrigenomic tests denotes lack of association with dietary intake and nutrient-related pathologies

Cristiana Pavlidis ${ }^{1}$, Zoi Lanara ${ }^{1,2}$, Angeliki Balasopoulou ${ }^{1}$, Jean-Christophe Nebel ${ }^{3}$, Theodora Katsila ${ }^{1}$, George P. Patrinos ${ }^{1}$,*

${ }^{1}$ University of Patras, School of Health Sciences, Department of Pharmacy, Patras, Greece

${ }^{2}$ University of Trieste, Faculty of Mathematical, Physical and Natural Sciences,

Department of Biological Sciences, Trieste, Italy

3 Kingston University, Faculty of Science, Engineering and Computing, School of Computing and Information Systems, London, United Kingdom 
Supplementary Figure 1. Conflicting gene association to condition (incompatible results).

Numbers next to the genes show the number of studies per gene.

Supplementary Figure 2. Conflicting associations to conditions (incompatible results). Numbers next to the genes show the number of studies per gene/SNP.

Supplementary Figure 3. Conflicting SNPs associations to links (incompatible results). The number of SNPs is shown vertically. The names of the links of diseases and conditions per SNP are shown horizontally.

Supplementary Figure 4. Conflicting gene associations to links (incompatible results). The number of genes is shown vertically. The names of the links of diseases' and conditions' groups per total number of genes are shown horizontally.

Supplementary Figure 5. Conflicting gene associations to links (incompatible results) to diseases and conditions. The number of genes is shown vertically. The names of the links of diseases and conditions are shown horizontally.

Supplementary Figure 6. Genes/SNPs and pathological conditions/diseases groups. The group names that correspond to the group numbers shown can be found in suppl. figure 1 . The black colour shows no statistical association between the SNPs and the pathological conditions/diseases groups.

Supplementary Figure 7. Conflicting results (number of studies) for the APOA5, CETP, IL6 and MTHFR genes and their link to CAD (n=17929, 18: «yes», 14: «no», 4: «may»). 
Supplementary Figure 8. Conflicting results (number of studies) for the PON1, LIPC and CETP genes and their link to CHD (coronary heart disease) (n=6119, 6: «yes», 9: «no», 4: «may»).

Supplementary Figure 9. Conflicting results (number of studies) for CRP, LIPC and IL6 genes and their link to CVD (n=31527, 21: «yes», 4: «no», 12: «may»)

Supplementary Figure 10. Conflicting results (number of studies) for the CRP and IL6 genes and their link to CRP levels and insulin resistance or only CRP levels ( $n=4199,5$ : «yes», 5: «no»).

Supplementary Figure 11. Conflicting results (number of studies) for the ADRB3, APOA5, APOC3 and CRP genes and their link to triglycerides (n=28528, 24: «yes», 10: «no», 11: «may»).

Supplementary Figure 12. Conflicting results (number of studies) for the $A D R B 3$ and $C R P$ genes and their link to obesity (n=3809, 3: «yes», 5: «no»).

Supplementary Figure 13. Conflicting results (number of studies) for the UCP2 and CETP genes and their link to BMI (n=2753, 2: «yes», 9: «no», 1:«may»). 
Supplementary Figure 14. Conflicting results (number of studies) for the ADRB2 and UCP2 genes and their link to diabetes ( $\mathrm{n}=3131,4:$ yes», 3: «no»,)

Supplementary Figure 15. Conflicting results (number of studies) for the ADRB2 and UCP2 genes and their link to HDL-C ( $\mathrm{n}=43989)$.

Supplementary Figure 16. Conflicting results (number of studies) for the ADRB2 and UCP2 genes and their link to metabolic syndrome (n=4599, 2: «yes», 9: «no»).

Supplemenary Figure 17. Conflicting results (number of studies) for the $L I P C$ gene and its link to total cholesterol ( $\mathrm{n}=8583,2:$ : $\mathrm{yes} », 6:$ :may»).

Supplementary Figure 18. Conflicting results (number of studies) for the ADRB2 gene and its link to total fat $(\mathrm{n}=1250,1: \ll y e s », 3: \ll$ no»)

Supplementary Figure 19. Conflicting results (number of studies) for the ADRB2 and $A D R B 3$ genes and their link to subcutaneous fat distribution ( $\mathrm{n}=1509,2:$ : yes», 4: «no»). 
Supplementary Figure 20. Conflicting results (number of studies) for the ADRB2 and $A D R B 3$ genes and their link to abdominal adiposity ( $\mathrm{n}=2446,2: \ll y e s », 4: \ll$ no»).

Supplementary Figure 21. Conflicting results (number of studies) for the $A D R B 2$ gene and its link to hypertension $(\mathrm{n}=8643,2:$ : $8 \mathrm{yes}, 4$ : «no»). 


\section{Supplementary References}

Aberle J, Evans D, Beil FU, and Seedorf U (2005). A polymorphism in the apolipoprotein A5 gene is associated with weight loss after short-term diet. Clin Genet 68(2), 152154.

Agachan B, Yilmaz H, Karaali Z, Iisbir T (2004). Paraoxonase 55 and 192 polymorphism and its relationship to serum paraoxonase activity and serum lipids in Turkish patients with non-insulin dependent diabetes mellitus. Cell Biochem Funct 22(3), 163-168.

Ahmad T, Chasman DI, Buring JE, Lee IM, Ridker PM, and Everett BM (2011). Physical activity modifies the effect of LPL, LIPC, and CETP polymorphisms on HDL-C levels and the risk of myocardial infarction in women of European ancestry. Circ Cardiovasc Genet 4(1), 74-80.

Akbarzadeh Najar R, Ghaderian SM, and Tabatabaei Panah AS (2012). C-reactive protein (CRP) gene polymorphisms: implication in CRP plasma levels and susceptibility to acute myocardial infarction. Mol Biol Rep 39(4), 3705-3712.

Aker S, Bantis C, Reis P, Kuhr N, Schwandt C, Grabensee B, et al. (2009). Influence of interleukin-6 $G-174 C$ gene polymorphism on coronary artery disease, cardiovascular complications and mortality in dialysis patients. Nephrology Dialysis Transplantion Sep 24(9), 2847-2851.

Al-Moundhri MS, Alkindy M, Al-Nabhani M, Al-Bahrani B, Burney IA, Al-Habsi H, et al. (2009). Combined polymorphism analysis of glutathione S-transferase M1/G1 and interleukin-1B $(I L-1 B) /$ interleukin 1-receptor antagonist $(I L-I R N)$ and gastric cancer risk in an Omani Arab Population. Journal of Clinical Gastroenterology Feb 43(2), 152-156. 
Almeida OP, Norman PE, Van Bockxmeer FM, Hankey GJ, and Flicker L (2012). CRP 1846G>A polymorphism increases risk of frailty. Maturitas Mar 71(3), 261-266.

Anand SS, Xie C, Paré G, Montpetit A, Rangarajan S, McQueen MJ, et al.(2009). Genetic variants associated with myocardial infarction risk factors in over 8000 individuals from five ethnic groups. The INTERHEART Genetics Study. Circulation: Cardiovascular Genetics 2, 16-25.

Andreotti G, Menashe I, Chen J, Chang SC, Rashid A, Gao YT, et al. (2009). Genetic determinants of serum lipid levels in Chinese subjects: a population-based study in Shanghai, China. European Journal of Epidemiology 24(12), 763-774.

Antonicelli R, Olivieri F, Bonafè M, Cavallone L, Spazzafumo L, Marchegiani F, et al. (2005). The interleukin-6 -174 $\mathrm{G}>\mathrm{C}$ promoter polymorphism is associated with a higher risk of death after an acute coronary syndrome in male elderly patients. International Journal of Cardiology Sep 1, 103(3), 266- 271.

Arca M, Campagna F, Montali A, Barilla F, Mangieri E, Tanzilli G, et al. (2000). The common mutations in the lipoprotein lipase gene in Italy: effects on plasma lipids and angiographically assessed coronary atherosclerosis. Clinical Genetics Nov 58(5), 369374.

Arca M, Montali A, Ombres D, Battiloro E, Campagna F, Ricci G, Verna R (2001). Lack of association of the common TaqIB polymorphism in the cholesteryl ester transfer protein gene with angiographically assessed coronary atherosclerosis. Clinical Genetics Nov 60(5), 374-380.

AshokKumar M, Subhashini NG, SaiBabu R, Ramesh A, Cherian KM, Emmanuel C, et al. (2010). Genetic variants on apolipoprotein gene cluster influence triglycerides with a risk of coronary artery disease among Indians. Molecular Biology Reports Jan 37(1), $521-527$. 
Asselbergs FW, Moore JH, van den Berg MP, Rimm EB, de Boer RA, Dullaart RP, et al. (2006). A role for CETP TaqIB polymorphism in determining susceptibility to atrial fibrillation: a nested case control study. BMC Medical Genetics Apr 19, 7, 39.

Aucella F, Margaglione M, Grandone E, Vigilante M, Gatta G, Forcella M et al (2005). The C677T methylenetetrahydrofolate reductase gene mutation does not influence cardiovascular risk in the dialysis population: results of a multicentre prospective study. Nephrol Dial Transplant Feb 20(2), 382-386.

Baki M, Akman FE, Vural P, Doğru-Abbasoğlu S, Özderya A, Karadağ B, et al. (2012). The combination of interleukin-10 -1082 and tumor necrosis factor $\alpha-308$ or 1nterleukin-6 -174 genes polymorphisms suggests an association with susceptibility to Hashimoto's thyroiditis. International Immunopharmacology Apr 12(4), 543-546.

Balcerzyk A, Zak I, and Krauze J (2007). Synergistic effects between Q192R polymorphism of paraoxonase 1 gene and some conventional risk factors in premature coronary artery disease. Archives of Medical Research Jul 38(5), 545-550.

Balcerzyk A, Zak I, and Krauze J (2008). Protective effect of R allele of PON1 gene on the coronary artery disease in the presence of specific genetic background. Disease Markers 24(2), 81-88.

Baldwin CT, Schwartz F, Baima J, Burzstyn M, DeStefano AL, Gavras I, et al. (1999). Identification of a polymorphic glutamic acid stretch in the a2B-adrenergic receptor and lack of linkage with essential hypertension. American Journal of Hypertension Sep 12(9 Pt 1), 853-857.

Bamoulid J, Courivaud C, Deschamps M, Gaugler B, Tiberghien P, Chalopin JM, et al. (2011). The Interleukin-6 gene promoter polymorphism -174 and atherosclerotic events in overweight transplanted patients. Corporation Journal of Transplantation $2011,803429$. 
Banerjee I, Pandey U, Hasan OM, Parihar R, Tripathi V, and Ganesh S (2009). Association between inflammatory gene polymorphisms and coronary artery disease in an Indian population. Journal of Thrombosis and Thrombolysis Jan 27(1), 88-94.

Bao XY, Peng B, and Yang MS (2012). Replication study of novel risk variants in six genes with type 2 diabetes and related quantitative traits in the Han Chinese lean individuals. Molecular Biology Reports Mar 39(3), 2447-2454.

Baum L, Tomlinson B, and Thomas GN (2003). APOA5-1131T $>\mathrm{C}$ polymorphism is associated with triglyceride levels in Chinese men. Clinical Genetics May 63(5), 377379.

Bengtsson K, Orho-Melander M, Melander O, Lindblad U, Ranstam J, and Råstam L (2001). Beta(2)-adrenergic receptor gene variation and hypertension in subjects with type 2 diabetes. Hypertension May 37(5), 1303-1308.

Bennermo M, Nordin M, Lundman P, Boqvist S, Held C, Samnegård A, et al. (2011). Genetic and environmental influences on the plasma interleukin- 6 concentration in patients with a recent myocardial infarction: A Case-Control study. Journal of Interferon \& Cytokine Research February 31(2), 259-264.

Bennet AM, van Maarle MC, Hallqvist J, Morgenstern R, Frostegård J, Wiman B, et al. (2006). Association of TNF-alpha serum levels and TNFA promoter polymorphisms with risk of myocardial infarction. Atherosclerosis Aug 187(2), 408-414.

Bernard N, Girouard J, Forest JC, and Giguere Y (2007). The combination of ApoCIII, hepatic lipase and hormone sensitive lipase gene polymorphisms suggests an association with susceptibility to gestational hypertension. Journal of Human Genetics $52(3), 244-254$.

Blankenberg S, Rupprecht HJ, Bickel C, Jiang XC, Poirier O, Lackner KJ, et al. (2003). Common genetic variation of the cholesteryl ester transfer protein gene strongly 
predicts future cardiovascular death in patients with coronary artery disease. Journal of the American College of Cardiology Jun 4, 41(11), 1983-9.

Block R, Corsetti J, Goldenberg I, Vorobiof G, McNitt S, Ryan D, et al. (2009). The common apolipoprotein A-1 polymorphism $-75 \mathrm{~A}>\mathrm{G}$ is associated with ethnic differences in recurrent coronary events after recovery from an acute myocardial infarction. Heart International Jun 30, 4(1), e8.

Bo S, Cassader M, Cavallo-Perin P, Durazzo M, Rosato R, and Gambino R (2012). The rs553668 polymorphism of the $A D R A 2 A$ gene predicts the worsening of fasting glucose values in a cohort of subjects without diabetes. A population-based study. Diabetic Medicine Apr 29(4), 549-552.

Bokor S, Csernus K, Erhardt E, Burus I, Molnár D, and Decsi T (2007). Association of n6 long-chain polyunsaturated fatty acids to $-866 \mathrm{G} / \mathrm{A}$ genotypes of the human uncoupling protein 2 gene in obese children. Acta Paediatrica Sep 96(9), 1350-1354.

Bos SD, Kloppenburg M, Suchiman E, Van Beelen E, Slagboom PE, and Meulenbelt I (2009). The role of plasma cytokine levels, $C R P$ and Selenoprotein $\mathrm{S}$ gene variation in OA. Osteoarthritis and Cartilage May 17(5), 621-626.

Bos SD, Suchiman HE, Kloppenburg M, Houwing-Duistermaat JJ, le Graverand MP, Seymour AB, et al. (2008). Allelic variation at the C-reactive protein gene associates to both hand osteoarthritis severity and serum high sensitive C-reactive protein levels in the GARP study. Annals of the Rheumatic Diseases Jun 67(6), 877879.

Brandalize AP, Bandinellia E, Dos Santos PA, and Schüler-Faccini L (2010). Maternal gene polymorphisms involved in folate metabolism as risk factors for Down syndrome offspring in Southern Brazil. Disease Markers 29(2), 95-101. 
Brinkley TE, Halverstadt A, Phares DA, Ferrell RE, Prigeon RL, Hagberg JM, et al. (2011). Hepatic lipase gene $-514 \mathrm{C}>\mathrm{T}$ variant is associated with exercise traininginduced changes in VLDL and HDL by lipoprotein lipase. Journal of Applied Physiology Dec 111(6), 1871-1876.

Brito DD, Fernandes AP, Gomes KB, Coelho FF, Cruz NG, Sabino AP, et al. (2011). Apolipoprotein A5-1131T $>\mathrm{C}$ polymorphism, but not $A P O E$ genotypes, increases susceptibility for dyslipidemia in children and adolescents. Molecular Biology Reports Oct 38(7), 4381-4388.

Brousseau ME, O’Connor JJ Jr, Ordovas JM, Collins D, Otvos JD, Massov T, et al. (2002). Cholesteryl ester transfer protein TaqI B2B2 genotype is associated with higher HDL cholesterol levels and lower risk of coronary heart disease end points in men with HDL deficiency veterans affairs HDL cholesterol intervention trial. Arteriosclerosis, Thrombosis, and Vascular Biology Jul 1, 22(7), 1148-1154.

Brull DJ, Montgomery HE, Sanders J, Dhamrait S, Luong L, Rumley A, et al. (2001). Interleukin-6 gene $-174 \mathrm{~g}>\mathrm{c}$ and $-572 \mathrm{~g}>\mathrm{c}$ promoter polymorphisms are strong predictors of plasma interleukin-6 levels after coronary artery bypass surgery. Arteriosclerosis, Thrombosis, and Vascular Biology Sep 21(9), 1458-1463.

Brull DJ, Serrano N, Zito F, Jones L, Montgomery HE, Rumley A, et al. (2003). Human $C R P$ gene polymorphism influences $C R P$ levels: implications for the prediction and pathogenesis of coronary heart disease. Arteriosclerosis, Thrombosis, and Vascular Biology Nov 1, 23(11), 2063-2069.

Burzotta F, Iacoviello L, Di Castelnuovo A, Glieca F, Luciani N, Zamparelli R, et al. (2001). Relation of the $-174 \mathrm{G} / \mathrm{C}$ polymorphism of interleukin-6 to interleukin-6 plasma levels and to length of hospitalization after surgical coronary revascularization. American Journal of Cardiology Nov 15, 88(10), 1125-1128. 
Büscher R, Herrmann V, Ring KM, Kailasam MT, O'Connor DT, Parmer RJ, et al. (1999). Variability in phenylephrine response and essential hypertension: A search for human a1B-adrenergic receptor polymorphisms. Journal of Pharmacology and Experimental Therapeutics Nov 291(2), 793-798.

Campo S, Sardo MA, Trimarchi G, Bonaiuto M, Castaldo M, Fontana L, et al. (2004). The paraoxonase promoter polymorphism $(-107) \mathrm{T}>\mathrm{C}$ is not associated with carotid intimamedia thickness in Sicilian hypercholesterolemic patients. Clinical Biochemistry May 37(5), 388- 394.

Campo S, Sardo MA, Trimarchi G, Bonaiuto M, Fontana L, Castaldo M, et al. (2004). Association between serum paraoxonase (PON1) gene promoter $\mathrm{T}(-107) \mathrm{C}$ polymorphism, PON1 activity and HDL levels in healthy Sicilian octogenarians. Experimental Gerontology Jul 39(7), 1089-1094.

Capoluongo E, Onder G, Concolino P, Russo A, Santonocito C, Bernabei R, et al. (2009). GSTM1-null polymorphism as possible risk marker for hypertension: results from the aging and longevity study in the Sirente Geographic Area (il SIRENTE study). Clinica Chimica Acta Jan 399(1-2), 92-96.

Chaaba R, Hammami S, Attia N, Smaoui M, Masmoudi AS, Mahjoub S, et al. (2005). Association of plasma cholesteryl ester transfer protein activity and polymorphism with coronary artery disease extent in Tunisian type II diabetic patients. Clinical Biochemistry Apr 38(4), 373- 378.

Chamberlain AM, Folsom AR, Schreiner PJ, Boerwinkle E, and Ballantyne CM (2008). Low-density lipoprotein and high-density lipoprotein cholesterol levels in relation to genetic polymorphisms and menopausal status: The Atherosclerosis Risk in Communities (ARIC) Study. Atherosclerosis Oct 200(2), 322-328. 
Chandak GR, Ward KJ, Yajnik CS, Pandit AN, Bavdekar A, Joglekar CV, et al. (2006). Triglyceride associated polymorphisms of the APOA5 gene have very different allele frequencies in Pune, India compared to Europeans. BMC Medical Genetics Oct 10, 7 , 76.

Charriere S, Bernard S, Aqallal M, Merlin M, Billon S, Perrot L, et al. (2008). Association of APOA5 -1131TNC and S19W gene polymorphisms with both mild hypertriglyceridemia and hyperchylomicronemia in type 2 diabetic patients. Clinica Chimica Acta Aug 394(1-2), 99-103.

Chaudhary R, Likidlilid A, Peerapatdit T, Tresukosol D, Srisuma S, Ratanamaneechat S, et al (2012). Apolipoprotein E gene polymorphism: effects on plasma lipids and risk of type 2 diabetes and coronary artery disease. Cardiovascular Diabetology Apr 23, 11, 36.

Chen C, Madeleine MM, Lubinski C, Weiss NS, Tickman EW, and Daling JR (1996). Glutathione S-transferase M1 genotypes and the risk of anal cancer: a populationbased case-control study. Cancer Epidemiology, Biomarkers \& Prevention Dec 5(12), 985-991.

Chen J, Yokoyama T, Saito K, Yoshiike N, Date C, and Tanaka H (2002). Association of human cholesteryl ester transfer protein-TaqI polymorphisms with serum HDL cholesterol levels in a normolipemic Japanese rural population. Journal of Epidemiology Mar 12(2), 77-84.

Chen J, Zhao J, Huang J, Su S, Qiang B, and Gu D (2005). -717A>G polymorphism of human C-reactive protein gene associated with coronary heart disease in ethnic Han Chinese: the Beijing atherosclerosis study. Journal of Molecular Medicine Jan 83(1), $72-78$. 
Chen QJ, Lu L, Jin C, Wang LJ, Zhang RY, Zhang Q, et al. (2010). Insertion/insertion genotype of $\alpha(2 \mathrm{~B})$-adrenergic receptor gene polymorphism is associated with silent myocardial ischemia in patients with type 2 diabetes mellitus. Clinical Biochemistry Oct 43(15), 1201-1204.

Chen YC, Chen YD, Li X, Post W, Herrington D, Polak JF, et al. (2009). The HMG-CoA reductase gene and lipid and lipoprotein levels: the multi-ethnic study of atherosclerosis. Lipids Aug 44(8), 733-743.

Chenevix-Trench G, Young J, Coggan M, and Board P (1995). Glutathione S-transferase $\mathrm{Ml}$ and $\mathrm{Tl}$ polymorphisms: susceptibility to colon cancer and age of onset. Carcinogenesis Jul 16(7), 1655-1657.

Chhabra S, Narang R, Lakshmy R, and Das N (2005). APO Al-75 G to A substitution associated with severe forms of CAD, lower levels of HDL and apoA-I among Northern Indians. Disease Markers 21(4), 169-174.

Chien KL, Hsu HC, Chen YC, Su TC, Lee YT, and Chen MF (2009). Association between sequence variant of c.553 $\mathrm{G}>\mathrm{T}$ in the apolipoprotein $\mathrm{A} 5$ gene and metabolic syndrome, insulin resistance, and carotid atherosclerosis. Translational Research: the Journal of Laboratory and Clinical Medicine Sep 154(3), 133-141.

Chistiakov DA, Zotova EV, Savostanov KV, Bursa TR, Galeev IV, Strokov IA, et al. (2006). The $262 \mathrm{~T}>\mathrm{C}$ promoter polymorphism of the catalase gene is associated with diabetic neuropathy in type 1 diabetic Russian patients. Diabetes and Metabolism Feb $32(1), 63-68$.

Chua KH, Kee BP, Tan SY, and Lian LH (2009). Interleukin-6 promoter polymorphisms ($174 \mathrm{G} / \mathrm{C}$ ) in Malaysian patients with systemic lupus erythematosus. Brazilian Journal Of Medical and Biological Research Jun 42, 551-555. 
Coker A, Arman A, Soylu O, Tezel T, and Yildirim A (2011). Lack of association between $I L-1$ and $I L-6$ gene polymorphisms and myocardial infarction in Turkish population. International Journal of Immunogenetics Jun 38(3), 201-208.

Combarros O, Van Duijn CM, Hammond N, Belbin O, Arias-Vásquez A, Cortina-Borja M, et al. (2009). Replication by the Epistasis Project of the interaction between the genes for $I L-6$ and $I L-10$ in the risk of Alzheimer's disease. Journal of Neuroinflammation Aug 23 (6), 22.

Conde AR, Martins G, Saraiva C, Rueff J, and Monteiro C (1999). Association of p53 genomic instability with the glutathione S-transferase null genotype in gastric cancer in the Portuguese population. Molecular Pathology Jun 52(3), 131-134.

Coppedè F, Tannorella P, Pezzini I, Migheli F, Ricci G, Caldarazzo lenco E, et al. (2012). Folate, homocysteine, vitamin B12, and polymorphisms of genes participating in onecarbon metabolism in late-onset Alzheimer's disease patients and healthy controls. Antioxidants and Redox Signaling Jul 15, 17(2), 195-204.

Couto FD, Adorno EV, Menezes JF, Moura Neto JP, Rêgo MA, Reis MG, et al. (2004). C677T polymorphism of the MTHFR gene and variant hemoglobins: a study in newborns from Salvador, Bahia, Brazil. Cadernos de Saúde Pública Mar-Apr 20(2), $529-533$.

Crispim D, Fagundes NJ, Dos Santos KG, Rheinheimer J, Bouças AP, de Souza BM, et al. (2010). Polymorphisms of the UCP2 gene are associated with proliferative diabetic retinopathy in patients with diabetes mellitus. Clinical Endocrinology May 72(5), $612-$ 619.

Cuchel M, Wolfe ML, deLemos AS, and Rader DJ (2002). The frequency of the cholesteryl ester transfer protein-TaqI B2 allele is lower in African Americans than in Caucasians. Atherosclerosis Jul 163(1), 169-174. 
Culpan D, MacGowan SH, Ford JM, Nicoll JA, Griffin WS, Dewar D, et al. (2003). Tumour necrosis factor-alpha gene polymorphisms and Alzheimer's disease. Neuroscience Letters Oct 16, 350(1), 61-65.

Daghestani MH, Warsy A, Daghestani MH, Al-odaib AN, Eldali A, Al-Eisa NA, et al. (2010). The Gln27Glu Polymorphism in b2-Adrenergic receptor gene is linked to hypertriglyceridemia, hyperinsulinemia and hyperleptinemia in Saudis. Lipids in Health and Disease Aug 25, 9, 90.

D'Aiuto F, Casas JP, Shah T, Humphries SE, Hingorani AD, and Tonetti MS (2005). Creactive protein $(+1444 \mathrm{C}>\mathrm{T})$ polymorphism influences $C R P$ response following a moderate inflammatory stimulus. Atherosclerosis Apr 179(2), 413-417.

D'Aiuto F, Parkar M, Brett PM, Ready D, and Tonetti MS (2004). Gene polymorphisms in pro-inflammatory cytokines are associated with systemic inflammation in patients with severe periodontal infections. Cytokine Oct 7, 28(1), 29-34.

Dallongeville J, Cottel D, Montaye M, Codron V, AmouyeL P, and Helbecque N (2006). Impact of $A P O A 5 / A 4 / C 3$ genetic polymorphisms on lipid variables and cardiovascular disease risk in French men. International Journal of Cardiology Jan 13, 106(2), $152-$ 156.

Dallongeville J, Helbecque N, Cottel D, Amouyel P, and Meirhaeghe A (2003). The Gly16-->Arg16 and Gln27-->Glu27 polymorphisms of beta2-adrenergic receptor are associated with metabolic syndrome in men. Journal of Clinical Endocrinology \& Metabolism Oct 88(10), 4862-4866.

Damcott CM, Feingold E, Moffett SP, Barmada MM, Marshall JA, and Hamman RF (2004). Genetic variation in uncoupling protein 3 is associated with dietary intake and body composition in females. Metabolism Apr 53(4), 458-464. 
De Grooth GJ, Zerba KE, Huang SP, Tsuchihashi Z, Kirchgessner T, Belder R, et al. (2004). The cholesteryl ester transfer protein (CETP) TaqIB polymorphism in the cholesterol and recurrent events study: no interaction with the response to pravastatin therapy and no effects on cardiovascular outcome: a prospective analysis of the CETP TaqIB polymorphism on cardiovascular outcome and interaction with cholesterollowering therapy. Journal of the American College of Cardiology Mar 3, 43(5), 854857.

Dedoussis GV, Panagiotakos DB, Louizou E, Mantoglou I, Chrysohoou C, Lamnisou K, et al. (2007). Cholesteryl ester-transfer protein (CETP) polymorphism and the association of acute coronary syndromes by obesity status in Greek subjects: the CARDIO2000-GENE study. Human Heredity 63(3-4), 155-161.

DeMichele A, Martin AM, Mick R, Gor P, Wray L, Klein-Cabral M, et al. (2003). Interleukin-6 -174G-->C polymorphism is associated with improved outcome in highrisk breast cancer. Cancer Research Nov 15, 63(22), 8051-8056.

Demirdöğen BC, Demirkaya S, Türkanoğlu A, Bek S, Arinç E, and Adali O (2009). Analysis of paraoxonase $1(P O N 1)$ genetic polymorphisms and activities as risk factors for ischemic stroke in Turkish population. Cell Biochemistry and Function Dec 27(8), 558-567.

Densem CG, Ray M, Hutchinson IV, Yonan N, and Brooks NH (2005). Interleukin-6 Polymorphism: A Genetic Risk Factor for Cardiac Transplant Related Coronary Vasculopathy? Journal of Heart and Lung Transplantation May 24(5), 559-565.

Di Renzo L, Bianchi A, Saraceno R, Calabrese V, Cornelius C, Iacopino L, et al. (2012). 174G/C IL-6 gene promoter polymorphism predicts therapeutic response to TNF- $\alpha$ blockers. Pharmacogenetics and Genomics Feb 22(2), 134-142. 
Dixit M, Bhattacharya S, and Mittal B (2005). Association of CETP TaqI and APOE polymorphisms with type II diabetes mellitus in North Indians: a case control study. BMC Endocrine Disorders Jul 1, 5, 7.

Doumatey AP, Chen G, Tekola Ayele F, Zhou J, Erdos M, Shriner D,et al. (2012). Creactive protein $(C R P)$ promoter polymorphisms influence circulating $\mathrm{CRP}$ levels in a genome-wide association study of African Americans. Human Molecular Genetics 21 (13), 3063-3072.

Duarte MM, Moresco RN, Duarte T, Santi A, Bagatini MD, Da Cruz IB et al. (2010). Oxidative stress in hypercholesterolemia and its association with Ala16Val superoxide dismutase gene polymorphism. Clinical Biochemistry Sep 43(13-14), 1118-1123.

Dunajska K, Lwow F, Milewicz A, Jedrzejuk D, Laczmanski L, Belowska-Bien K, et al. (2008). beta(3)-adrenergic receptor polymorphism and metabolic syndrome in postmenopausal women. Gynecological Endocrinology Mar 24(3), 133-138.

Duran-Gonzalez J, Ortiz I, Gonzales E, Ruiz N, Ortiz M, Gonzalez A, et al. (2011). Association Study of Candidate Gene Polymorphisms and Obesity in a Young Mexican-American Population from South Texas. Archives of Medical Research Aug 42(6), 523-531.

Eiriksdottir G, Bolla MK, Thorsson B, Sigurdsson G, Humphries SE, and Gudnason V (2001). The $-629 \mathrm{C}>\mathrm{A}$ polymorphism in the CETP gene does not explain the association of TaqIB polymorphism with risk and age of myocardial infarction in Icelandic men. Atherosclerosis Nov 159(1), 187-192.

Elosua R, Cupples LA, Fox CS, Polak JF, D’Agostino RA Sr, Wolf PA, et al. (2006). Association between well-characterized lipoprotein-related genetic variants and carotid intimal medial thickness and stenosis: The Framingham Heart Study. Atherosclerosis Nov 189(1), 222-228. 
Enquobahrie DA, Smith NL, Bis JC, Carty CL, Rice KM, Lumley T, et al. (2008). Cholesterol ester transfer protein, interleukin-8, peroxisome proliferator activator receptor alpha, and Toll-like receptor 4 genetic variations and risk of incident nonfatal myocardial infarction and ischemic stroke. American Journal of Cardiology Jun 15, 101(12), 1683-1688.

Eriksson UK, Pedersen NL, Reynolds CA, Hong MG, Prince JA, Gatz M, et al. (2011). Associations of gene sequence variation and serum levels of Creactive protein and Interleukin-6 with Alzheimer's disease and dementia. Journal of Alzheimer's Disease 23(2), 361-369.

Esterbauer H, Schneitler C, Oberkofler H, Ebenbichler C, Paulweber B, Sandhofer F, et al. (2001). A common polymorphism in the promoter of UCP2 is associated with decreased risk of obesity in middle-aged humans. Nature Genetics Jun 28(2), 178-183.

Eussen SJ, Vollset SE, Igland J, Meyer K, Fredriksen A, Ueland PM, et al. (2010). Plasma folate, related genetic variants and colorectal cancer risk in EPIC. Cancer Epidemiology, Biomarkers \& Prevention May 19(5), 1328-1340.

Evans D, Seedorf U, and Beil FU (2005). Polymorphisms in the apolipoprotein A5 (APOA5) gene and type III hyperlipidemia. Clinical Genetics Oct 68(4), 369-372.

Falchi A, Giovannoni L, Piras IS, Calo CM, Moral P, Vona G, et al. (2005). Prevalence of genetic risk factors for coronary artery disease in Corsica island (France). Experimental and Molecular Pathology Dec 79(3), 210-213.

Fan WH, Liu DL, Xiao LM, Xie CJ, Sun SY, and Zhang JC (2011). Coronary heart disease and chronic periodontitis: is polymorphism of interleukin-6 gene the common risk factor in a Chinese population? Oral Diseases Apr 17(3), 270-276.

Fan YM, Raitakari OT, Kahonen M, Hutri-Kahonen N, Juonala M, Marniemi J, et al. (2009). Hepatic lipase promoter C-480T polymorphism is associated with serum lipids 
levels, but not subclinical atherosclerosis: The Cardiovascular Risk in Young Finns Study. Clinical Genetics Jul 76(1), 46-53.

Fava C, Montagnana M, Guerriero M, Almgren P, von Wowern F, Minuz P, et al. (2009). Chromosome 2q12, the ADRA2B I/D polymorphism and metabolic syndrome. Journal of Hypertension Sep 27(9), 1794-1803.

Fidani L, Hatzitolios AI, Goulas A, Savopoulos C, Basayannis C, and Kotsis A (2005). Cholesteryl ester transfer protein TaqI B and lipoprotein lipase Ser447Ter gene polymorphisms are not associated with ischaemic stroke in Greek patients. Neuroscience Letters Aug 12-19, 384(1-2), 102-105.

Fintelman-Rodrigues N, Corrêa JC, Santos JM, Pimentel MM, and Santos-Rebouças CB (2009). Investigation of $C B S, M T R, R F C-1$ and $T C$ polymorphisms as maternal risk factors for Down syndrome. Disease Markers 26(4), 155-161.

Flex A, Gaetani E, Pola R, Santoliquido A, Aloi F, Papaleo P, et al. (2002). The -174 G/C Polymorphism of the Interleukin-6 gene promoter is associated with peripheral artery occlusive disease. European Journal of Vascular and Endovascular Surgery Sep 24(3), 264-268.

Franceschini A, Szklarczyk D, Frankild S, Kuhn M, Simonovic M, Roth A, et al. (2013). STRING v9.1: protein-protein interaction networks, with increased coverage and integration. Nucleic Acids Research Jan 41(Database issue), D808-815.

Freeman DJ, Samani NJ, Wilson V, McMahon AD, Braund PS, Cheng S, et al. (2003). A polymorphism of the cholesteryl ester transfer protein gene predicts cardiovascular events in non-smokers in the West of Scotland Coronary Prevention Study. European Heart Journal Oct 24(20), 1833-1842. 
Freitas SR, Pereira AC, Floriano MS, Mill JG, and Krieger JE (2008). Association of alpha1a-adrenergic receptor polymorphism and blood pressure phenotypes in the Brazilian population. BMC Cardiovascular Disorders Dec 23, 8, 40.

Fung MM, Salem RM, Lipkowitz MS, Bhatnagar V, Pandey B, Schork NJ, et al. (2012). Methylenetetrahydrofolate reductase (MTHFR) polymorphism A1298C (Glu429Ala) predicts decline in renal function over time in the African-American Study of Kidney Disease and Hypertension (AASK) Trial and Veterans Affairs Hypertension Cohort (VAHC). Nephrology Dialysis Transplantation Jan 27(1), 197-205.

Gallone S, Di Stefano M, Fenoglio P, Rubino E, Criasia A, Pinessi L, et al. (2011). Proinflammatory cytokine gene polymorphisms and susceptibility to Paget's disease of bone: an association study. Cytokine Dec 56(3), 560-563.

Garcia-Gonzalez MA, Savelkoul PH, Benito R, Santolaria S, Crusius JB, Peña AS, et al. (2005). No allelic variant associations of the $I L-1$ and $T N F$ gene polymorphisms in the susceptibility to duodenal ulcer disease. International Journal of Immunogenetics Oct 32(5), 299-306.

Gardemann A, Weidemann H, Philipp M, Katz N, Tillmanns H, Hehrlein FW, et al. (1999). The TT genotype of the methylenetetrahydrofolate reductase C677T gene polymorphism is associated with the extent of coronary atherosclerosis in patients at high risk for coronary artery disease. European Heart Journal Apr 20(8), 584-592.

Garza-González E, Bosques-Padilla FJ, El-Omar E, Hold G, Tijerina-Menchaca R, Maldonado-Garza HJ, et al. (2005). Role of the polymorphic $I L-1 B, I L-1 R N$ and TNF-A genes in distal gastric cancer in Mexico. International Journal of Cancer Mar $20,114(2), 237-241$. 
Gaustadnes M, Ørntoft TF, Jensen JL, and Torring N (2006). Validation of the Use of DNA pools and primer extension in association studies of sporadic colorectal cancer for selection of candidate SNPs. Human Mutation Feb 27(2), 187-194.

Gaysina D, Pierce M, Richards M, Hotopf M, Kuh D, and Hardy R (2011). Association between adolescent emotional problems and metabolic syndrome: The modifying effect of C-reactive protein gene $(C R P)$ polymorphisms. Brain, Behavior, and Immunity May 25(4), 750-758.

Gbandjaba NY, Ghalim N, Hassar M, Berrougui H, Labrazi H, Taki H, et al. (2012). Paraoxonase activity in healthy, diabetic, and hemodialysis patients. Clinical Biochemistry Apr 45(6), 470-474.

Genelhu VA, Francischetti EA, Duarte SF, Celoria BM, Oliveira RC, Cabello PH, et al. (2010). Beta3-adrenergic receptor polymorphism is related to cardiometabolic risk factors in obese Brazilian subjects. Genetics and Molecular Research 9(3), 1392-1397.

George S, Ruan XZ, Navarrete C, Turner D, Reynard M, Sweny P, et al. (2004). Renovascular disease is associated with low producer genotypes of the antiinflammatory cytokine interleukin-10. Tissue Antigens May 63(5), 470-475.

Georges JL, Loukaci V, Poirier O, Evans A, Luc G, Arveiler D, et al. (2001). Interleukin-6 gene polymorphisms and susceptibility to myocardial infarction: the ECTIM study. Journal of Molecular Medicine Jun 79(5-6), 300-305.

Gertig DM, Stampfer M, Haiman C, Hennekens CH, Kelsey K, and Hunter DJ (1998). Glutathione S-transferase GSTM1 and GSTT1 polymorphisms and colorectal cancer risk: a prospective study. Cancer Epidemiology, Biomarkers \& Prevention Nov 7(11), 1001-1005.

Ghazouani L, Ben Hadj Khalifa S, Abboud N, Ben Hamda K, Ben Khalfallah A, Brahim N, et al. (2010). TNF-alpha $-308 \mathrm{G}>\mathrm{A}$ and IL-6 $-174 \mathrm{G}>\mathrm{C}$ polymorphisms in Tunisian 
patients with coronary artery disease. Clinical Biochemistry Sep 43(13-14), 10851089.

Gjesing AP, Andersen G, Burgdorf KS, Borch-Johnsen K, Jørgensen T, Hansen T, et al. (2007). Studies of the associations between functional beta2-adrenergic receptor variants and obesity, hypertension and type 2 diabetes in 7,808 white subjects. Diabetologia Mar 50(3), 563-568.

Glas J, Török HP, Schneider A, Brünnler G, Kopp R, Albert ED, et al. (2004). Allele 2 of the interleukin-1 receptor antagonist gene is associated with early gastric cancer. Journal of Clinical Oncology Dec 1, 22(23), 4746-4752.

Goldenberg I, Moss AJ, Block R, Ryan D, Corsetti JP, McNitt S, et al. (2007). Polymorphism in the Cholesteryl Ester Transfer Protein gene and the risk of early onset myocardial infarction among cigarette smokers. Annals of noninvasive electrocardiology 12 (4), 364-374.

Goodarzi MO, Guo X, Taylor KD, Quiñones MJ ,Saad MF, Yang H, et al. (2004). Lipoprotein lipase is a gene for insulin resistance in Mexican Americans. Diabetes Jan 53(1), 214-220.

Gough J, Karplus K, Hughey R, and Chothia C (2001). Assignment of homology to genome sequences using a library of hidden Markov models that represent all proteins of known structure. Journal of Molecular Biology Nov 2, 313(4), 903-919.

Goto A, Sasai K, Suzuki S, Fukutomi T, Ito S, Matsushita T, et al. (2001). Cholesteryl ester transfer protein and atherosclerosis in Japanese subjects: a study based on coronary angiography. Atherosclerosis Nov 159(1), 153-163.

Goyenechea E, Parra D, and Martínez JA (2007). Impact of interleukin 6 -174G>C polymorphism on obesity-related metabolic disorders in people with excess in body weight. Metabolism Clinical and Experimental Dec 56(12), 1643-1648. 
Grarup N, Andreasen CH, Andersen MK, Albrechtsen A, Sandbæk A, Lauritzen T, BorchJohnsen K, et al. (2008). The $-250 \mathrm{G}>\mathrm{A}$ promoter variant in hepatic lipase associates with elevated fasting serum high-density lipoprotein cholesterol modulated by interaction with physical activity in a study of 16,156 Danish subjects. The Journal of Clinical Endocrinology and Metabolism Jun 93(6), 2294-2299.

Grassi G, Padmanabhan S, Menni C, Seravalle G, Lee WK, Bombelli M, et al. (2011). Association between ADRA1A gene and the metabolic syndrome: candidate genes and functional counterpart in the PAMELA population. Journal of Hypertension Jun 29(6), $1121-1127$.

Gu D, Ge D, Snieder H, He J, Chen S, Huang J, et al. (2006). Association of alpha1A adrenergic receptor gene variants on chromosome 8p21 with human stage 2 hypertension. Journal of Hypertension Jun 24(6), 1049-1056.

Gudnason V, Kakko S, Nicaud V, Savolainen MJ, Kesäniemi YA, Tahvanainen E, et al. (1999). Cholesteryl ester transfer protein gene effect on CETP activity and plasma high-density lipoprotein in European populations. The EARS Group. European Journal of Clinical Investigation Feb 29(2), 116-128.

Guéant-Rodriguez RM, Juillière Y, Candito M, Adjalla CE, Gibelin P, Herbeth B, et al. (2005). Association of MTRRA66G polymorphism (but not of MTHFR C677T and A1298C, MTRA2756G, TCN C776G) with homocysteine and coronary artery disease in the French population. Thrombosis and Haemostasis Sep 94(3), 510-515.

Gueuvoghlanian-Silva BY, Torloni MR, Mattar R, de Oliveira LS, Scomparini FB, Nakamura MU, et al. (2012). Profile of inflammatory mediators in gestational diabetes mellitus: phenotype and genotype. American Journal of Reproductive Immunology Mar 67(3), 241-250. 
Gupta N, Binu KB, Singh S, Maturu NV, Sharma YP, Bhansali A, et al. (2012). Low serum PON1 activity: An independent risk factor for coronary artery disease in NorthWest Indian type 2 diabetics. Gene Apr 25, 498(1), 13-19.

Guzmán-Guzmán IP, Muñoz-Valle JF, Flores-Alfaro E, Salgado-Goytia L, SalgadoBernabé AB, and Parra-Rojas I (2010). Interleukin-6 gene promoter polymorphisms and cardiovascular risk factors. A family study. Disease Markers 28(1), 29-36.

Han Z, Heath SC, Shmulewitz D, Li W, Auerbach SB, Blundell ML, Lehner T, et al. (2002). Candidate Genes Involved in Cardiovascular Risk Factors by a Family-Based Association Study on the Island of Kosrae, Federated States of Micronesia. American Journal of Medical Genetics Jul 1, 110(3), 234-242.

Hermann M, Fischer D, Hoffmann MM, Gasser T, Quitzau K, Meinertz T, et al. (2012). CRP and CD14 polymorphisms correlate with coronary plaque volume in patients with coronary artery disease - IVUS substudy of the ENCORE trials. Atherosclerosis Jan, 220(1), 172-176.

Hezova R, Bienertova-Vasku J, Sachlova M, Brezkova V, Vasku A, Svoboda M, et al. (2012). Common polymorphisms in GSTM1, GSTT1, GSTP1, GSTA1 and susceptibility to colorectal cancer in the Central European population. European Journal of Medical Research Jun 14, 17, 17.

Hokanson J, Kamboh MI, Scarboro S, Eckel RH, and Hamman RF (2003). Physical Activity on Coronary Heart Disease Risk. American Journal of Epidemiology Nov 1, 158(9), 836-843.

Hozyasz KK, Mostowska A, Szaflarska-Poplawska A, Lianeri M, and Jagodzinski PP (2012). Polymorphic variants of genes involved in homocysteine metabolism in celiac disease. Molecular Biology Reports Mar, 39(3), 3123-3130. 
Hsieh MC, Tien KJ, Chang SJ, Lo CS, Hsin SC, Hsiao JY, et al. (2007). Cholesteryl ester transfer protein B1B1 genotype as a predictor of coronary artery disease in Taiwanese with type 2 diabetes mellitus. Metabolism: Clinical and Experimental Jun, 56(6), 745750.

Hsu FC, Sides EG, Mychaleckyj JC, Worrall BB, Elias GA, Liu Y, et al. (2011). Transcobalamin 2 variant associated with poststroke homocysteine modifies recurrent stroke risk. Neurology Oct 18, 77(16), 1543-1550.

Hsu LA, Ko YL, Chang CJ, Hu CF, Wu S, Teng MS, et al. (2006). Genetic variations of apolipoprotein $A 5$ gene is associated with the risk of coronary artery disease among Chinese in Taiwan. Atherosclerosis Mar 185(1), 143-149.

Hu C, Zhang R, Wang C, Wang J, Ma X, Hou X, et al. (2010). Variants from GIPR, TCF7L2, DGKB, MADD, CRY2, GLIS3, PROX1, SLC3OA8 and IGF1 are associated with glucose metabolism in the Chinese. PLoS One Nov 17, 5(11), e15542.

Huang K, Sandler RS, Millikan RC, Schroeder JC, North KE, and Hu J (2006). GSTM1 and GSTT1 polymorphisms, cigarette smoking, and risk of colon cancer: a populationbased case-control study in North Carolina (United States). Cancer Causes and Control May 17(4), 385-394.

Hubacek JA, Lanska V, Skodová Z, Adámková V, and Poledn R (2008). Sex-specific interaction between $A P O E$ and $A P O A 5$ variants and determination of plasma lipid levels. European Journal of Human Genetics Jan 16(1), 135-138.

Hulkkonen J, Lehtimäki T, Mononen N, Juonala M, Hutri-Kähönen N, Taittonen L, et al. (2009). Polymorphism in the IL6 promoter region is associated with the risk factors and markers of subclinical atherosclerosis in men: The Cardiovascular Risk in Young Finns Study. Atherosclerosis Apr 203(2), 454-458. 
Humphries SE, Luong LA, Ogg MS, Hawe E, and Miller GJ (2001). The interleukin-6 $-174 \mathrm{G} / \mathrm{C}$ promoter polymorphism is associated with risk of coronary heart disease and systolic blood pressure in healthy men. European Heart Journal Dec 22(24), 22432252.

Hung AM, Ikizler TA, Griffin MR, Glenn K, Greevy RA, Grijalva CG, et al. (2011). CRP polymorphisms and chronic kidney disease in the third national health and nutrition examination survey. BMC Medical Genetics May 11, 12, 65.

Isaacs A, Aulchenko YS, Hofman A, Sijbrands EJ, Sayed-Tabatabaei FA, Klungel OH, et al. (2007). Epistatic effect of Cholesteryl Ester Transfer Protein and Hepatic Lipase on serum High-Density Lipoprotein cholesterol levels. The Journal of Clinical Endocrinology \& Metabolism 92(7), 2680-2687.

Isbir T, Yilmaz H, Agachan B and Karaali ZE (2003). Cholesterol ester transfer protein, apolipoprotein $\mathrm{E}$ and lipoprotein lipase genotypes in patients with coronary artery disease in the Turkish population. Clinical Genetics Sep 64(3), 228-234.

Ishiyama-Shigemoto S, Yamada K, Yuan X, Ichikawa F, and Nonaka K (1999). Association of polymorphisms in the beta2-adrenergic receptor gene with obesity, hypertriglyceridaemia, and diabetes mellitus. Diabetologia Jan 42(1), 98-101.

Israni AK, Li N, Sidhwani S, Rosas S, Kong X, Joffe M, et al. (2007). Association of hypertension genotypes and decline in renal function after kidney transplantation. Transplantation Nov 27, 84(10), 1240-1247.

Jang Y, Kim OY, Hyun YJ, Chae JS, Koh SJ, Heo YM, et al. (2008). Interleukin-6$572 \mathrm{C}>\mathrm{G}$ polymorphism-association with inflammatory variables in Korean men with coronary artery disease. Translational Research Mar 151(3), 154-161.

Jeng JR, Wang JH, Liu WS, Chen SP, Chen MY, Wu MH, et al. (2005). Association of interleukin-6 gene G-174C polymorphism and plasma plasminogen activator inhibitor- 
1 level in Chinese patients with and without hypertension. American Journal of Hypertension Apr 18(4 Pt 1), 517-522.

Jenny NS, Tracy RP, Ogg MS, Luong le A, Kuller LH, Arnold AM, et al. (2002). In the elderly, interleukin-6 plasma levels and the $-174 \mathrm{G}>\mathrm{C}$ polymorphism are associated with the development of cardiovascular disease.Arteriosclerosis, Thrombosis, and Vascular Biology Dec 1, 22(12), 2066-2071.

Jensen MK, Mukamal KJ, Overvad K, and Rimm EB (2008). Alcohol consumption, TaqIB polymorphism of cholesteryl ester transfer protein, high-density lipoprotein cholesterol, and risk of coronary heart disease in men and women. European Heart Journal Jan 29(1), 104-112.

Ji Q, Ikegami H, Fujisawa T, Kawabata Y, Ono M, Nishino M, et al. (2004). A common polymorphism of uncoupling protein 2 gene is associated with hypertension. Journal of Hypertension Jan 22(1), 97-102.

Jokić M, Brčić-Kostić K, Stefulj J, Catela Ivković T, Božo L, Gamulin M, et al. (2011). Association of MTHFR, MTR, MTRR, RFC1, and DHFR gene polymorphisms with susceptibility to sporadic colon cancer. DNA and Cell Biology Oct 30(10), 771-776.

Jones KG, Brull DJ, Brown LC, Sian M, Greenhalgh RM, Humphries SE, et al. (2001). Interleukin-6 (IL-6) and the prognosis of abdominal aortic aneurysms.Circulation May 8, 103(18), 2260-2265.

Kakko S, Tamminen M, Päivänsalo M, Kauma H, Rantala AO, Lilja M, et al. (2001). Variation at the cholesteryl ester transfer protein gene in relation to plasma high density lipoproteins cholesterol levels and carotid intima-media thickness. European Journal of Clinical Investigation Jul 31(7), 593-602. 
Kampman E, Slattery ML, Bigler J, Leppert M, Samowitz W, Caan BJ, et al. (1999). Meat consumption, genetic susceptibility, and colon cancer risk:A United States multicenter case-control study. Cancer Epidemiology, Biomarkers \& Prevention January 8, 15.

Kang JM, Kim N, Lee DH, Park JH, Lee MK, Kim JS, et al. (2009). The effects of genetic polymorphisms of $I L-6, I L-8$, and $I L-10$ on Helicobacter pylori-induced gastroduodenal diseases in Korea. Journal of Clinical Gastroenterology May-Jun 43(5), 420-428.

Kang JX (2012). Identification of Metabolic Biomarkers for personalised nutrition. Journal of Nutrigenetics and Nutrigenomics 5 (2), I-II.

Karayannis G, Tsezou A, Giannatou E, Papanikolaou V, Giamouzis G, and Triposkiadis F (2010). Polymorphisms of renin-angiotensin system and natriuretic peptide receptor A genes in patients of Greek origin with a history of myocardial infarction. Angiology Nov 61(8), 737-743.

Kathiresan S, Larson MG, Vasan RS, Guo CY, Gona P, Keaney JF Jr, et al. (2006). Contribution of clinical correlates and 13 C-reactive protein gene polymorphisms to interindividual variability in serum C-reactive protein level. Circulation Mar 21, 113(11), 1415-1423.

Kawasaki I, Tahara H, Emoto M, Shoji T, and Nishizawa Y (2002). Relationship between TaqIB cholesteryl ester transfer protein gene polymorphism and macrovascular complications in Japanese patients with type 2 diabetes. Diabetes Mar 51(3), 871-874.

Kayaaltı Z, Sahiner L, Durakoğlugil ME, and Söylemezoğlu T (2011). Distributions of interleukin-6 (IL-6) promoter and metallothionein 2A (MT2A) core promoter region gene polymorphisms and their associations with aging in Turkish population. Archives of Gerontology and Geriatric Nov-Dec 53(3), 354-358. 
Keenan BT, Chibnik LB, Cui J, Ding B, Padyukov L, Kallberg H, et al. (2010). Effect of interactions of glutathione S-transferase $T 1, M 1$, and $P 1$ and $H M O X 1$ gene promoter polymorphisms with heavy smoking on the risk of rheumatoid arthritis. Arthritis \& Rheumatism Nov 62(11), 3196-3210.

Kelberman D, Hawe E, Luong LA, Mohamed-Ali V, Lundman P, Tornvall P, et al. (2004). Effect of Interleukin-6 promoter polymorphisms in survivors of myocardial infarction and matched controls in the North and South of Europe. The HIFMECH Study. Thrombosis and Haemostasis Nov 92(5), 1122-1128.

Kesarwani P, and Mittal RD (2010). Association of pro/anti-inflammatory cytokine gene polymorphisms with benign prostate hyperplasia risk. Indian Journal of Clinical Biochemistry 4, 342-348.

Kesarwani P, Mandhani A, and Mittal RD (2009). Polymorphisms in tumor necrosis factor-A gene and prostate cancer risk in North Indian cohort. The Journal of Urology December 182(6), 2938-2943.

Kettunen T, Eklund C, Kähönen M, Jula A, Päivä H, Lyytikäinen LP, et al. (2011). Polymorphism in the C-reactive protein $(C R P)$ gene affects CRP levels in plasma and one early marker of atherosclerosis in men: The Health 2000 Survey. Scandinavian Journal of Clinical \& Laboratory Investigation Sep 71(5), 353-361.

Khovidhunkit W, Chartyingcharoen P, Siriwong S, Limumpornpetch P, and Plengpanich W (2012). Resequencing CETP, LIPC and LIPG Genes in Thai subjects with Hyperalphalipoproteinemia. American Journal of Cardiology Jul 1, 110(1), 62-66.

Kim JM, Stewart R, Kim SW, Yang SJ, Shin IS, Shin HY, et al. (2008). Methylenetetrahydrofolate reductase gene and risk of Alzheimer's disease in Koreans.. International Journal of Geriatric Psychiatry May 23(5), 454-459. 
Kim N, Cho SI, Yim JY, Kim JM, Lee DH, Park JH, et al. (2006). The effects of genetic polymorphisms of $I L-1$ and $T N F-A$ on Helicobacter pylori-induced gastroduodenal diseases in Korea. Helicobacter Apr 11(2), 105-112.

Kim SH, Kim DJ, Seo IA, Min YK, Lee MS, Kim KW, et al. (2002). Significance of beta2-Adrenergic Receptor gene polymorphism in obesity and type 2 diabetes mellitus in Korean subjects. Metabolism: Clinical and Experimental Jul 51(7), 833-837.

Kiss I, Németh A, Bogner B, Pajkos G, Orsós Z, Sándor J, et al. (2004). Polymorphisms of glutathione-S-transferase and arylamine $\mathrm{N}$-acetyltransferase enzymes and susceptibility to colorectal cancer. Anticancer Research Nov-Dec 24(6), 3965-3970.

Kordi-Tamandani DM, Hashemi M, Sharifi N, Kaykhaei MA, and Torkamanzehi A (2012). Association between paraoxonase-1 gene polymorphisms and risk of metabolic syndrome. Molecular Biology Reports Feb 39(2), 937-943.

Kosokabe T, Okumura K, Sone T, Kondo J, Tsuboi H, Mukawa H, et al. (2001). Relation of a common methylenetetrahydrofolate reductase mutation and plasma homocysteine with intimal hyperplasia after coronary stenting. Circulation Apr 24, 103(16), 20482054.

Kring SI, Larsen LH, Holst C, Toubro S, Hansen T, Astrup A, et al. (2008). Genotypephenotype associations in obesity dependent on definition of the obesity phenotype. Obesity Facts 1(3), 138-45.

Kuhlenbaeumer G, Huge A, Berger K, Kessler C, Voelzke H, Funke H,et al. (2010). Genetic variants in the C-reactive protein gene are associated with microangiopathic ischemic stroke. Cerebrovascular Diseases 30(5), 476-482.

Kunugi H, Nanko S, Ueki A, Otsuka E, Hattori M, Hoda F, et al. (1997). High and low activity alleles of catechol-O-methyltransferase gene: ethnic difference and possible association with Parkinson's disease. Neuroscience Letters Jan 17, 221(2-3), 202-204. 
Laaksonen DE, Siitonen N, Lindström J, Eriksson JG, Reunanen P, Tuomilehto J, Finnish Diabetes Prevention Study Group., et al. (2007). Physical activity, diet, and incident diabetes in relation to an $A D R A 2 B$ polymorphism.Medicine \& Science in Sports \& Exercise Feb 39(2), 227-232.

Ladero JM, Martínez C, García-Martin E, Fernández-Arquero M, López-Alonso G, De la Concha EG, et al. (2005). Polymorphisms of the glutathione S-transferases mu-1 (GSTM1) and theta-1 (GSTT1) and the risk of advanced alcoholic liver disease. Scandinavian Journal of Gastroenterology Mar 40(3), 348-353.

Ladero JM, Martínez C, García-Martín E, Ropero P, Briceño O, Villegas A, et al. (2006). Glutathione S-transferase M1 and T1 genetic polymorphisms are not related to the risk of hepatocellular carcinoma: a study in the Spanish population. European Journal of Cancer Jan 42(1), 73-77.

Lallas T.A., McClain SK, Shahin MS, and Buller RE. (2000). The Glutathione STransferase M1 Genotype in Ovarian Cancer. Cancer Epidemiology, Biomarkers \& Prevention Jun 9(6), 587-590.

Laraqui A, Allami A, Raisonnier A, Coiffard AS, Benkouka F, Bendriss A, et al. (2007). Relation between plasma homocysteine, gene polymorphisms of homocysteine metabolism-related enzymes, and angiographically proven coronary artery disease. European Journal of Internal Medicine Oct 18(6), 474-483.

Latkovskis G, Licis N, and Kalnins U (2004). C-reactive protein levels and common polymorphisms of the interleukin-1 gene cluster and interleukin-6 gene in patients with coronary heart disease. European Journal of Immunogenetics Oct 31(5), 207-213.

Laukkanen JA, Mäkikallio TH, Kauhanen J, and Kurl S (2009). Insertion/deletion polymorphism in $\alpha 2$-adrenergic receptor gene is a genetic risk factor for sudden cardiac death. American Heart Journal Oct 158(4), 615-621. 
Lazaros L, Markoula S, Kyritsis A, and Georgiou I (2010). Paraoxonase gene polymorphisms and stroke severity. European Journal of Neurology May 17(5), 757759.

Le Goff W, Guerin M, Nicaud V, Dachet C, Luc G, Arveiler D, et al. (2002). A novel cholesteryl ester transfer protein promoter polymorphism $(-971 \mathrm{G} / \mathrm{A})$ associated with plasma high-density lipoprotein cholesterol level Interaction with the TaqIB and -629C/A polymorphisms. Atherosclerosis 161, 269-279.

Le Goff W, Guerin M, Nicaud V, Dachet C, Luc G, Arveiler D, et al. (2002). A novel cholesteryl ester transfer protein promoter polymorphism $(-971 \mathrm{G} / \mathrm{A})$ associated with plasma high-density lipoprotein cholesterol levels. Interaction with the TaqIB and -629C/A polymorphisms. Atherosclerosis Apr 161(2), 269-279.

Lee HJ, Ryu HJ, Shin HD, Park BL, Kim JY, Cho YM, et al. (2008). Associations between polymorphisms in the mitochondrial uncoupling proteins (UCPs) with T2DM. Clinica Chimica Acta Dec 398(1-2), 27-33.

Lee JY, Kim HY, Kim KH, Kim SM, Jang MK, Park JY, et al. (2005). Association of polymorphism of $I L-10$ and $T N F-A$ genes with gastric cancer in Korea. Cancer Letters Jul 28, 225(2), 207-214.

Lee KW, Ayyobi AF, Frohlich JJ, and Hill JS (2004). APOA5 gene polymorphism modulates levels of triglyceride, HDL cholesterol and FERHDL but is not a risk factor for coronary artery disease. Atherosclerosis Sep 176(1), 165-172.

Lee YH, Bae SC, Choi SJ, Ji JD, and Song GG (2012). Genome-wide pathway analysis of genome-wide association studies on systemic lupus erythematosus and rheumatoid arthritis. Molecular Biology Reports Dec 39(12), 10627-10635.

Lee YH, Kim W, Yu BC, Park BL, Kim LH, and Shin HD (2008). Association of the ins/del polymorphisms of uncoupling protein $2(U C P 2)$ with BMI in a Korean 
population. Biochemical and Biophysical Research Communications Jul 11, 371(4), 767-771.

Leshinsky-Silver E, Cheng S, Grow MA, Shoshana S, Scharf L, Lev, et al. (2006) Candidate gene polymorphism in cardiovascular disease: The BIP cohort. The Israel Medical Association journal: IMAJ Feb 8(2), 103-105.

Leung WK, Chan MC, To KF, Man EP, Ng EK, Chu ES, et al. (2006). H. pylori genotypes and cytokine gene polymorphisms influence the development of gastric intestinal metaplasia in a Chinese population. The American Journal of Gastroenterology Apr 101(4), 714-720.

Li D, Dandara C, and Parker MI. The 341C/T polymorphism in the GSTP1 gene is associated with increased risk of oesophageal cancer. BMC Genetics Jun 11, 11, 47.

Li GP, Wang JY, Yan SK, Chen BS, Xue H, and Wu G (2004). Genetic effect of two polymorphisms in the apolipoprotein $A 5$ gene and apolipoprotein $C 3$ gene on serum lipids and lipoproteins levels in a Chinese population. Clinical Genetics Jun 65(6), $470-476$.

$\mathrm{Li} \mathrm{H}$, Chen XL, and Li HQ (2005). Polymorphism of CYPIAl and GSTMI genes associated with susceptibility of gastric cancer in Shandong Province of China. World Journal of Gastroenterology Oct 7, 11(37), 5757-5762.

Li J, Huang A, Hu Y, and Chen D (2008). Association of the lipoprotein lipase gene $\mathrm{T}+495 \mathrm{G}$ polymorphism with central obesity and serum lipids in a twin study. Annals of Epidemiology 18, Oct 18(10), 760-767.

Li JL, Canham RM, Vongpatanasin W, Leonard D, Auchus RJ, and Victor RG (2006). Do allelic variants in alpha2A and alpha2C adrenergic receptors predispose to hypertension in blacks? Hypertension Jun 47(6), 1140-1146. 
Li LH, Li Y, Wen Y, and Wang JG (2008). Anthropometric and metabolic phenotypes in relation to the $A D R A 2 B$ deletion/insertion polymorphism in Chinese population. Journal of Hypertension Nov 26(11), 2161-2167.

Li Z, Sun L, Zhang H, Liao Y, Wang D, Zhao B, et al. (2003). Elevated plasma homocysteine was associated with hemorrhagic and ischemic stroke, but methylenetetrahydrofolate reductase gene C677T polymorphism was a risk factor for thrombotic stroke: a Multicenter Case-Control Study in China. Stroke Sep 34(9), 2085-2090.

Limer KL, Tosh K, Bujac SR, McConnell R, Doherty S, Nyberg F, et al. (2009). Attempt to replicate published genetic associations in a large, well-defined osteoarthritis case control population (the GOAL study). Osteoarthritis and Cartilage Jun 17(6), 782-789.

Lin FH, Chu NF, Lee CH, Hung YJ, and Wu DM (2011). Combined effect of C-reactive protein gene SNP +2147 A/G and interleukin-6 receptor gene SNP rs2229238 C/T on anthropometric characteristics among school children in Taiwan. International Journal of Obesity 2011 Apr 35(4), 587-594.

Lindholm E, Klannemark M, Agardh E, Groop L, and Agardh CD (2004). Putative role of polymorphisms in UCP1-3 genes for diabetic nephropathy. Journal of Diabetes and Its Complications Mar-Apr 18(2), 103-107.

Lindi V, Schwab U, Louheranta A, Vessby B, Hermansen K, Tapsell L KANWU Study Group, et al. (2008). The G-250A polymorphism in the hepatic lipase gene promoter is associated with changes in hepatic lipase activity and LDL cholesterol.The KANWU Study. Nutrition, Metabolism \& Cardiovascular Diseases February Volume 18, Issue 2, Pages 88-95. 
Liu J, Sun K, Bai Y, Zhang W, Wang X, Wang Y, et al. (2009). Association of three-gene interaction among MTHFR, ALOX5AP and NOTCH3 with thrombotic stroke: a multicenter case-control study. Human Genetics Jun 125(5-6), 649-56.

Liu S, Schmitz C, Stampfer MJ, Sacks F, Hennekens CH, Lindpaintner K, and Ridker PM (2002). A prospective study of TaqIB polymorphism in the gene coding for cholesteryl ester transfer protein and risk of myocardial infarction in middle-aged men. Atherosclerosis Apr 161(2), 469-474.

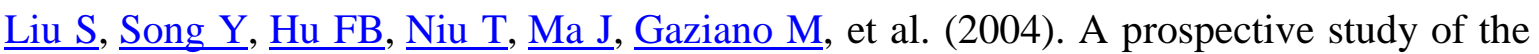
APOA1 XmnI and APOC3 SstI polymorphisms in the APOA1/C3/A4 gene cluster and risk of incident myocardial infarction in men. Atherosclerosis Nov 177(1), 119-126.

Ljungman P, Bellander T, Nyberg F, Lampa E, Jacquemin B, Kolz M, et al. (2009). DNA variants, plasma levels and variability of Interleukin-6 in myocardial infarction survivors: Results from the AIRGENE study. Thrombosis Research May 124(1), 5764.

Lockette W, Ghosh S, Farrow S, MacKenzie S, Baker S, Miles P, et al. (1995). Alpha 2adrenergic receptor gene polymorphism and hypertension in blacks. American Journal of Hypertension Apr 8(4 Pt 1), 390-394.

López-Mejías R, García-Bermúdez M, González-Juanatey C, Castañeda S, Pérez-Esteban S, Miranda-Filloy JA, et al. (2011). Lack of association between IL6 single nucleotide polymorphisms and cardiovascular disease in Spanish patients with rheumatoid arthritis. Atherosclerosis Dec 219(2), 655-658.

López-Ruiz A, Jarabo MM, Martínez-Triguero ML, Morales-Suárez-Varela M, Solá E, Bañuls C, et al. (2009). Small and dense LDL in familial combined hyperlipidemia and N291S polymorphism of the lipoprotein lipase gene. Lipids in Health and Disease $\operatorname{Mar} 31,8,12$. 
Lovati E, Richard A, Frey BM, Frey FJ, and Ferrari P (2001). Genetic polymorphisms of the renin-angiotensin-aldosterone system in end-stage renal disease. Kidney International Jul 60(1), 46-54.

Lu Y, Feskens EJ, Boer JM, Imholz S, Verschurenb WM, Wijmenga C, et al. (2010). Exploring genetic determinants of plasma total cholesterol levels and their predictive value in a longitudinal study. Atherosclerosis Nov 213(1), 200-205.

Lynch AI, Eckfeldt JH, Davis BR, Ford CE, Boerwinkle E, Leiendecker-Foster C, et al. (2012). Gene panels to help identify subgroups at high and low risk of coronary heart disease among those randomized to antihypertensive treatment: the GenHAT study. Pharmacogenetics and Genomics May 22(5), 355-366.

Macdonald HM, McGuigan FE, Fraser WD, New SA, Ralston SH, and Reid DM (2004). Methylenetetrahydrofolate reductase polymorphism interacts with riboflavin intake to influence bone mineral density. Bone Oct 35(4), 957-964.

Maitra A, Shanker J, Dash D, John S, Sannappa PR, Rao VS, et al. (2008). Polymorphisms in the IL6 gene in Asian Indian families with premature coronary artery disease - The Indian Atherosclerosis Research Study. Thrombosis and Haemostasis May 99(5), 944950.

Mälarstig A, Wallentin L, and Siegbahn A (2007). Genetic variation in the interleukin-6 gene in relation to risk and outcomes in acute coronary syndrome. Thrombosis Research 119(4), 467-73.

Mancini FP, Sabatino L, Colantuoni V, Pasanisi F, Finelli C, Contaldo F, et al. (2003). Variants of uncoupling protein-2 gene and obesity: interaction with peroxisome proliferator-activated receptorgamma2. Clinical Endocrinology Dec 59(6), 817-822. 
Manginas A, Tsiavou A, Chaidaroglou A, Giamouzis G, Degiannis D, Panagiotakos D, et al. (2008). Inflammatory cytokine gene variants in coronary artery disease patients in Greece. Coronary Artery Disease Dec 19(8), 575-582.

Manraj M, Francke S, Hébé A, Ramjuttun US, and Froguel P (2001). Genetic and environmental nature of the insulin resistance syndrome in Indo-Mauritian subjects with premature coronary heart disease: contribution of $\beta 3$-adrenoreceptor gene polymorphism and beta-blockers on triglyceride and HDL concentrations. Diabetologia January Volume 44, Issue 1, 115-122.

Margaglione M, Bossone A, Cappucci G, Colaizzo D, Grandone E, and Di Minno G (2001). The effect of interleukin-6 C/G-174 polymorphism and circulating interleukin6 on fibrinogen plasma levels. Haematologica Feb 86(2), 199-204.

Markan S, Sachdeva M, Sehrawat BS, Kumari S, Jain S, and Khullar M (2007). MTHFR 677 CT/MTHFR $1298 \mathrm{CC}$ genotypes are associated with increased risk of hypertension in Indians. Molecular and Cellular Biochemistry Aug 302(1-2), 125-131.

Marso SP, House JA, and Hopkins PJ (2006). Increase in interleukin-6 following arterial injury is related to insulin resistance, the $-174 \mathrm{G} \rightarrow \mathrm{C}$ polymorphism and complex plaque morphology. International Journal of Immunogenetics Oct 33(5), 347-354.

Marti A, Corbalán MS, Forga L, Martinez-González MA, and Martinez JA (2004). Higher Obesity Risk Associated With the Exon-8 Insertion of the UCP2 Gene in a Spanish Case-Control Study. Nutrition Jun 20(6), 498-501.

Martinelli N, Trabetti E, Bassi A, Girelli D, Friso S, Pizzolo F, et al. (2007). The -1131 T $>\mathrm{C}$ and S19W APOA5 gene polymorphisms are associated with high levels of triglycerides and apolipoprotein C-III, but not with coronary artery disease: an angiographic study. Atherosclerosis Apr 191(2), 409-417. 
Martinez JA, Parra MD, Santos JL, Moreno-Aliaga MJ, Marti A, and Martinez-Gonzalez MA (2008). Genotype-dependent response to energy-restricted diets in obese subjects: towards personalized nutrition. Asia Pacific Journal of Clinical Nutrition 17 Suppl 1, 119-122.

Martinez-Hervas S, Mansego ML, de Marco G, Martinez F, Alonso MP, Morcillo S, et al. (2012). Polymorphisms of the UCP2 gene are associated with body fat distribution and risk of abdominal obesity in Spanish population. European Journal of Clinical Investigation Feb 42(2), 171-178.

Masoudi M, Saadat I, Omidvari S, and Saadat M (2009). Genetic polymorphisms of GSTO2, GSTM1, and GSTT1 and risk of gastric cancer. Molecular Biology Reports Apr 36(4), 781-784.

Masud R, and Qureshi Iz (2011). Tetra primer ARMS-PCR relates folate/homocysteine pathway genes and $A C E$ gene polymorphism with coronary artery disease. Molecular and Cellular Biochemistry Sep 355(1-2), 289-297.

Masuo K, Katsuya T, Fu Y, Rakugi H, Ogihara T, and Tuck ML (2005). Lys418Asn polymorphism of the a2-adrenoreceptor gene relates to serum uric acid levels but not to insulin sensitivity. Hypertension Jul 46(1), 144-150.

Matsunaga T, Gu N, Yamazaki H, Tsuda M, Adachi T, Yasuda K, et al. (2009). Association of $U C P 2$ and $U C P 3$ polymorphisms with heart rate variability in Japanese men. Journal of Hypertension Feb 27(2), 305-313.

Mazza A, Motti C, Nulli A, Marra G, Gnasso A, Pastore A, et al. (2000). Lack of association between carotid intima-media thickness and methylenetetrahydrofolate reductase gene polymorphism or serum homocysteine in non-insulin-dependent diabetes mellitus. Metabolism: Clinical and Experimental Jun 49(6), 718-723. 
Mei Q, Xu JM, Cao HL, Bao DM, Hu NZ, Zhang L, et al. (2009). Associations of the IL-1 and $T N F$ gene polymorphisms in the susceptibility to duodenal ulcer disease in Chinese Han population. International Journal of Immunogenetics Feb 37(1), 9-12.

Mendonça MI, Dos Reis RP, Freitas AI, Sousa AC, Pereira A, Faria P, et al. (2009). Genegene interaction affects coronary artery disease risk. Revista Portuguesa de Cardiologia Apr 28(4), 397-415.

Mendoza-Carrera F, Ramírez-López G, Ayala-Martínez NA, García-Zapién AG, FloresMartínez SE, and Sánchez-Corona J (2010). Influence of CRP, IL6, and TNFA gene polymorphisms on circulating levels of C-reactive protein in Mexican adolescents. Archives of Medical Research. Aug 41(6), 472-477.

Merino A, Gayá A, Segura I, Calvo J, Imízcoz C, Berenguel A, et al. (2004). Platelet aggregation inhibition blocks C-reactive protein and interleukin-6 (IL-6) elevation after the coronary angioplasty: effect of the -174 G/C IL-6 gene polymorphism. American Journal of Cardiology Nov 15, 94(10), 1300-1303.

Miljkovic-Gacic I, Bunker CH, Ferrell RE, Kammerer CM, Evans RW, Patrick AL, et al. (2006). Lipoprotein subclass and particle size differences in Afro-Caribbeans, African Americans, and white Americans: association with hepatic lipase gene variation. Metabolism Clinical and Experimental Jan 55(1), 96-102.

Miller DT, Zee RY, Suk Danik J, Kozlowski P, Chasman DI, Lazarus R, et al. (2005). Association of Common CRP Gene Variants with CRP Levels and Cardiovascular Events. Annals of Human Genetics Nov 69(Pt 6), 623-638.

Miltiadous G, Hatzivassiliou M, Liberopoulos E, Bairaktari E, Tselepis A, Cariolou M, et al. (2005). Gene polymorphisms affecting HDL-cholesterol levels in the normolipidemic population. Nutrition, Metabolism \& Cardiovascular Diseases Volume 15, Issue 3, 219-224. 
Mohrschladt MF, Van Der Sman-De Beer F, Hofman MK, Van Der Krabben M, Westendorp RG, and Smelt AH (2005). TaqIB polymorphism in CETP gene: the influence on incidence of cardiovascular disease in statin-treated patients with familial hypercholesterolemia. European Journal of Human Genetics Jul 13(7), 877-882.

Montjean D, Benkhalifa M, Dessolle L, Cohen-Bacrie P, Belloc S, Siffroi JP, et al. (2011). Polymorphisms in MTHFR and MTRR genes associated with blood plasma homocysteine concentration and sperm counts. Fertility and Sterility Feb 95(2), 635640.

Moore LE, Hung R, Karami S, Boffetta P, Berndt S, Hsu CC, et al. (2008). Folate metabolism genes, vegetable intake and renal cancer risk in central Europe. International Journal of Cancer Apr 15, 122(8), 1710-1715.

Morcillo S, Cardona F, Rojo-Martínez G, Almaraz MC, Esteva I, Ruiz-De-Adana MC, et al. (2008). Effect of the combination of the variants $-75 \mathrm{G} / \mathrm{A}$ APOAl and Trp64Arg $A D R B 3$ on the risk of type 2 diabetes (DM2). Clinical Endocrinology Jan 68(1), 102107.

Morita A, Nakayama T, and Soma M (2006). Association Study Between C-Reactive Protein Genes and Ischemic Stroke in Japanese Subjects. American Journal of Hypertension. Jun, 19(6), 593-600.

Mostowska A, Myka M, Lianeri M, Roszak A, and Jagodziński PP (2011). Folate and choline metabolism gene variants and development of uterine cervical carcinoma. Clinical Biochemistry Jun 44(8-9), 596-600.

Mottagui-Tabar S, Hoffstedt J, Brookes AJ, Jiao H, Arner P, and Dahlman I (2008). Association of $A D R B 1$ and $U C P 3$ gene polymorphisms with insulin sensitivity but not obesity. Hormone Research 69(1), 31-36. 
Mu LN, Lu QY, Yu SZ, Cao W, You NC, Setiawan VW, et al. (2005). Green tea drinking and multigenetic index on the risk of stomach cancer in a Chinese population. Int Journal of Cancer Oct 10, 116(6), 972-983.

Murata M, Maruyama T, Suzuki Y, Saruta T, and Ikeda Y (2004). Paraoxonase 1192 Gln/Arg polymorphism is associated with the risk of microangiopathy in Type 2 diabetes mellitus. Diabetic Medicine Aug 21(8), 837-844.

Murtaugh MA, Sweeney C, Ma KN, Caan BJ, and Slattery ML (2005). The CYP1A1 Genotype May Alter the Association of Meat Consumption Patterns and Preparation with the Risk of Colorectal Cancer in Men and Women. Journal of Nutrition Feb135(2), 179-186.

Nagano T, Matsuda Y, Tanioka T, Yoshioka T, Hiroi T, Yoshikawa K, et al. (2005). No association of the Trp64Arg mutation of the $\beta 3$-adrenergic receptor gene with obesity, type 2 diabetes mellitus, hyperlipidemia, and hypertension in Japanese patients with schizophrenia. The Journal of Medical Investigation February 52, 57-64.

Nan HM, Song YJ, Yun HY, Park JS, and Kim H (2005). Effects of dietary intake and genetic factors on hypermethylation of the $h M L H 1$ gene promoter in gastric cancer. World Journal of Gastroenterology Jul 7, 11(25), 3834-3841.

Ng DP, Nurbaya S, Ye SH, and Krolewski AS (2008). An IL-6 haplotype on human chromosome $7 \mathrm{p} 21$ confers risk for impaired renal function in type 2 diabetic patients. Kidney International Aug 74(4), 521-527.

Ocho MC, Santos JL, Azcona C, Moreno-Aliaga MJ, Martínez-González MA, Martínez JA GENOI Members, et al. (2007). Association between obesity and insulin resistance with UCP2-UCP3 gene variants in Spanish children and adolescents. Molecular Genetics and Metabolism Dec 92(4), 351-358. 
Ognjanovic S, Yamamoto J, Saltzman B, Franke A, Ognjanovic M, Yokochi L, et al. (2010). Serum $C R P$ and $I L-6$, genetic variants and risk of colorectal adenoma in a multiethnic population. Cancer Causes and Control Jul 21(7), 1131-1138.

Oizumi T, Daimon M, Saitoh T, Kameda W, Yamaguchi H, Ohnuma H, et al. (2001). Genotype Arg/Arg, but not Trp/Arg, of the Trp64Arg polymorphism of the beta(3)adrenergic receptor is associated with type 2 diabetes and obesity in a large Japanese sample. Diabetes Care Sep 24(9), 1579-1583.

Ong KL, Jiang CQ, Liu B, Jin YL, Tso AW, Tam S, et al. (2011). Association of a genetic variant in the apolipoprotein $A 5$ gene with the metabolic syndrome in Chinese. Clinical Endocrinology Feb 74(2), 206-213.

Ordovas JM, Corella D, Demissie S, Cupples LA, Couture P, Coltell O, et al. (2002). Dietary fat intake determines the effect of a common polymorphism in the hepatic lipase gene promoter on high-density lipoprotein metabolism: evidence of a strong dose effect in this gene-nutrient interaction in the Framingham Study. Circulation Oct 29, 106(18), 2315-2321.

Ott K, Lordick F, Becker K, Ulm K, Siewert J, Höfler H, and Keller G (2008). Glutathione-S-transferase P1, T1 and M1 genetic polymorphisms in neoadjuvanttreated locally advanced gastric cancer: GSTM1-present genotype is associated with better prognosis in completely resected patients. International Journal of Colorectal Disease Aug 23(8), 773-782.

Özdemir BH, Özdemir FN, Ataç FB, Özdemir AA, and Haberal M (2011). Angiotensinogen t235 and angiotensin-converting enzyme insertion/deletion polymorphisms associated with the development of posttransplantation diabetes mellitus in renal allograft recipients. Transplantation Proceedings Mar 43(2), 572-574. 
Özdemir O, Gundogdu F, Karakelleoglu S, Sevimli S, Pirim I, Acikel M, et al. (2008). Comparison of serum levels of inflammatory markers and allelic variant of interleukin-6 in patients with acute coronary syndrome and stable angina pectoris. Coronary Artery Disease Feb 19(1), 15-19.

Ozturk Z, Enkhmaa B, Shachter NS, Berglund L, and Anuurad E (2010). Integrated role of two apoliprotein E polymorphisms on apolipoprotein B levels and coronary artery disease in a biethnic population. Metabolic Syndrome and Related Disorders Dec 8(6), $531-538$.

Paik JK, Kim OY, Koh SJ, Jang Y, Chae JS, Kim JY, et al. (2007). Additive effect of interleukin-6 and C-reactive protein $(C R P)$ single nucleotide polymorphism on serum CRP concentration and other cardiovascular risk factors. Clinica Chimica Acta May 1, 380(1-2), 68-74.

Palli D, Saieva C, Gemma S, Masala G, Gomez-Miguel MJ, Luzzi I, et al. (2005). GSTT1 and GSTM1 gene polymorphisms and gastric cancer in a high-risk Italian population. International Journal of Cancer Jun 10, 115(2), 284-289.

Panoulas $\quad$ VF, Douglas $\quad$ KM, Smith JP, Stavropoulos-Kalinoglou A, Metsios GS, Nightingale P, et al. (2009). Transforming growth factor- $\beta 1869 \mathrm{~T} / \mathrm{C}$, but not interleukin-6 -174G/C, polymorphism associates with hypertension in rheumatoid arthritis. Oxford Journals Medicine Rheumatology Feb 48(2), 113-118.

Panoulas VF, Stavropoulos-Kalinoglou A, Metsios GS, Smith JP, Milionis HJ, Douglas KM, et al. (2009). Association of interleukin-6 (IL-6)-174G/C gene polymorphism with cardiovascular disease in patients with rheumatoid arthritis: The role of obesity and smoking. Atherosclerosis May 204(1), 178-183.

Pantelidis P, Fanning GC, Wells AU, Welsh KI, and Du Bois RM (2001). Analysis of tumor necrosis factor-alpha, lymphotoxin-alpha, tumor necrosis factor receptor II, and 
interleukin-6 polymorphisms in patients with idiopathic pulmonary fibrosis. American Journal of Respiratory and Critical Care Medicine May 163(6), 1432-1436.

Papanas N, Papatheodorou K, Papazoglou D, Kotsiou S, Christakidis D, and Maltezos E (2007). An insertion/deletion polymorphism in the alpha2B adrenoceptor gene is associated with peripheral neuropathy in patients with type 2 diabetes mellitus. Experimental and Clinical Endocrinology \& Diabetes 115(5), 327-330.

Papazoglou D, Papathanasiou P, Papanas N, Papatheodorou K, Chatziangeli E, Nikitidis I, et al. (2012). Uncoupling protein-2 45-base pair Insertion/Deletion Polymorphism: Is there an association with severe obesity and weight loss in morbidly obese subjects? Metabolic Syndrome and Related Disorders Aug 10(4), 307-311.

Papazoglou D, Papanas N, Papatheodorou K, Kotsiou S, Christakidis D, and Maltezos E (2006). An insertion/deletion polymorphism in the alpha2B adrenoceptor gene is associated with age at onset of type 2 diabetes mellitus. Experimental and Clinical Endocrinology \& Diabetes Sep 114(8), 424-427.

Park HS, Shin ES, and Lee JE (2008). Genotypes and haplotypes of $\beta 2$-adrenergic receptor and parameters of the metabolic syndrome in Korean adolescents. Metabolism Clinical and Experimental Aug 57(8), 1064-1070.

Pávková Goldbergová M, Spinarová L, Spinar J, Pařenica J, Sišková L, Groch L, et al. (2011). Difference in angiotensinogen haplotype frequencies between chronic heart failure and advanced atherosclerosis patients - new prognostic factor?. Physiological Research 60(1), 55-64.

Pei Y, Scholey J, Thai K, Suzuki M, and Cattran D (1997). Association of angiotensinogen gene T235 variant with progression of immunoglobin A nephropathy in Caucasian patients. The Journal of Clinical Investigation Aug 15, 100(4), 814-820. 
Peloso GM, Demissie S, Collins D, Mirel DB, Gabriel SB, Cupples LA, et al. (2010). Common genetic variation in multiple metabolic pathways infl uences susceptibility to low HDL-cholesterol and coronary heart disease. The Journal of Lipid Research Dec 51(12), 3524-3532.

Pepe C, Guidugli L, Sensi E, Aretini P, D’Andrea E, Montagna M, et al. (2007). Methyl group metabolism gene polymorphisms as modifier of breast cancer risk in Italian BRCA1/2 carriers. Breast Cancer Research and Treatment May 103(1), 29-36.

Pérez-Bravo F, Echiburú B, Maliqueo M, Santos JL, and Sir-Petermann T (2005). Tryptophan $64 \rightarrow$ arginine polymorphism of $\beta$-3-adrenergiC receptor in Chilean women with polycystic ovary syndrome. Clinical Endocrinology Feb 62(2), 126-131.

Pinelli M, Giacchetti M, Acquaviva F, Cocozza S, Donnarumma G, Lapice E, et al. (2006). Beta2-adrenergic receptor and UCP3 variants modulate the relationship between age and type 2 diabetes mellitus. BMC Medical Genetics Dec 6, 7, 85.

Plat AW, Stoffers HE, de Leeuw PW, van Schayck CP, Soomers FL, Kester AD, et al. (2009). The influence of six cardiovascular polymorphisms on a first event of ischemic heart disease is modified by sex and age. Coronary Artery Disease Dec 20(8), 499-505.

Plengpanich W, Siriwong S, and Khovidhunkit W(2009). Two novel mutations and functional analyses of the CETP and LIPC genes underlying severe hyperalphalipoproteinemia. Metabolism Clinical and Experimental Aug 58(8), 11781184.

Pola R, Flex A, Gaetani E, Pola P, and Bernabei R (2002). The -174 G/C polymorphism of the interleukin-6 gene promoter and essential hypertension in an elderly Italian population. Journal of Human Hypertension Sep 16(9), 637-640. 
Polterauer S, Grimm C, Zeillinger R, Heinze G, Tempfer C, Reinthaller A, et al. (2011). Association of C-Reactive Protein $(C R P)$ gene polymorphisms, serum CRP levels and cervical cancer prognosis. Anticancer Research Jun 31(6), 2259-2264.

Prasad P, Tiwari AK, Kumar KM, Ammini AC, Gupta A, Gupta R, et al. (2006). Chronic renal insufficiency among Asian Indians with type 2 diabetes: I. Role of $R A A S$ gene polymorphisms. BMC Medical Genetics May 3, 7, 42.

Qi L, Liu S, Rifai N, Hunter D, and Hu FB (2007). Associations of the apolipoprotein A1/C3/A4/A5 gene cluster with triglyceride and HDL cholesterol levels in women with type 2 diabetes. Atherosclerosis May192(1), 204-210.

Qiu LX, Wang K, Lv FF, Chen ZY, Liu X, Zheng CL, et al. (2011). GSTM1 null allele is a risk factor for gastric cancer development in Asians. Cytokine Jul 55(1), 122-125.

Ramu P, Rajan S, Shewade DG, Swaminathan RP, Dutta TK, Balachander J, et al. (2009). Genetic Variants of $\beta 1$-adrenoceptor gene polymorphsims (Ser49Gly and Arg389Gly) and essential hypertension in a South Indian Tamil population. Clinical and Experimental Pharmacology and Physiology May/June Volume 36, Issue 5-6, 576582.

Rance KA, Johnstone AM, Murison S, Duncan JS, Wood SG, and Speakman JR (2007). Plasma leptin levels are related to body composition, sex, insulin levels and the A55V polymorphism of the UCP2 gene. International Journal of Obesity Aug 31(8), 13111318.

Rauramaa R, Väisänen SB, Luong LA, Schmidt-Trücksäss A, Penttilä IM, Bouchard C, et al. (2000). Stromelysin-1 and interleukin-6 gene promoter polymorphisms are determinants of asymptomatic carotid artery atherosclerosis. Arteriosclerosis, Thrombosis, and Vascular Biology Dec 20(12), 2657-2662. 
Relvas WG, Izar MC, Helfenstein T, Fonseca MI, Colovati M, Oliveira A, et al. (2005). Relationship between gene polymorphisms and prevalence of myocardial infarction among diabetic and non-diabetic subjects. Atherosclerosis Jan 178(1), 101-105.

Renström F, Shungin D, Johansson I; MAGIC Investigators, Florez JC, Hallmans G, et al. (2011). Genetic predisposition to long-term nondiabetic deteriorations in glucose homeostasis: Ten-year follow-up of the GLACIER study. Diabetes Jan 60(1), 345354.

Rezaieyazdi Z, Afshari JT, Sandooghi M, and Mohajer F (2007). Tumour necrosis factor a -308 promoter polymorphism in patients with rheumatoid arthritis. Rheumatology International Dec 28(2), 189-191.

Richterova B, Stich V, Moro C, Polak J, Klimcakova E, Majercik M, et al.(2004). Effect of endurance training on adrenergic control of lipolysis in adipose tissue of obese women. The Journal of Clinical Endocrinology and Metabolism Mar 89(3), 13251331

Rios DL, Cerqueira CC, Bonfim-Silva R, Araújo LJ, Pereira JF, Gadelha SR, et al. (2010). Interleukin-1 beta and interleukin-6 gene polymorphism associations with angiographically assessed coronary artery disease in Brazilians. Cytokine Jun 50(3), 292-296.

Risselada AJ, Vehof J, Bruggeman R, Wilffert B, Cohen D, Al Hadithy AF, et al. (2010). Association between the $1291-\mathrm{C} / \mathrm{G}$ polymorphism in the adrenergic $\alpha-2 \mathrm{a}$ receptor and the metabolic syndrome. Journal of Clinical Psychopharmacology Dec 30(6), 667-671.

Roest M, Jansen AC, Barendrecht A, Leus FR, Kastelein JJ, and Voorbij HA (2005). Variation at the paraoxonase gene locus contributes to carotid arterial wall thickness in subjects with familial hypercholesterolemia. Clinical Biochemistry Feb 38(2), 123 127. 
Rooyen JM, Pretorius PJ, Britz M, Huisman HW, Schutte AE, Towers GW, et al. (2008). Genetic polymorphisms of beta2- and beta3-adrenergic receptor genes associated with characteristics of the metabolic syndrome in black South African women. Experimental and Clinical Endocrinology and Diabetes Apr 116(4), 236-240.

Rosmond R, Bouchard C, and Björntorp P (2002). A C-1291G polymorphism in the alpha2A-adrenergic receptor gene $(A D R A 2 A)$ promoter is associated with cortisol escape from dexamethasone and elevated glucose levels. Journal of Internal Medicine Mar 251(3), 252-257.

Ruiz-Narváez EA, Yang Y, Nakanishi Y, Kirchdorfer J, and Campos H (2005). APOC3/A5 haplotypes, lipid levels, and risk of myocardial infarction in the Central Valley of Costa Rica. The Journal of Lipid Research Dec 46(12), 2605-2613.

Rundek T, Elkind MS, Pittman J, Boden-Albala B, Martin S, Humphries SE, et al. (2002). Carotid intima-media thickness is associated with allelic variants of stromelysin-1, interleukin-6, and hepatic lipase genes The Northern Manhattan Prospective Cohort Study. Stroke May 33(5), 1420-1423.

Saad AA, O'Connor PJ, Mostafa MH, Metwalli NE, Cooper DP, Povey AC, et al. (2005). Polymorphisms of the glutathione S-transferases mu-1 (GSTM1) and theta-1 (GSTT1) and the risk of advanced alcoholic liver disease. Scandinavian Journal of Gastroenterology Mar 40(3), 348-353.

Sagiv-Friedgut K, Karban A, Weiss B, Shaoul R, Shamir R, Bujanover Y, et al. (2010). Early-onset Crohn disease is associated with male sex and a polymorphism in the $I L-6$ promoter. Journal of Pediatric Gastroenterology and Nutrition Jan 50(1), 22-26.

Sánchez-Moreno C, Ordovás JM, Smith CE, Baraza JC, Lee YC, and Garaulet M (2011). APOA5 gene variation interacts with dietary fat intake to modulate obesity and 
circulating triglycerides in a Mediterranean population. Journal of Nutrition Mar 141(3), 380-385.

Sanders J, Hawe E, Brull DJ, Hubbart C, Lowe GD, Rumley A, et al. (2009). Higher IL-6 levels but not $I L 6-174 \mathrm{G}>\mathrm{C}$ or $-572 \mathrm{G}>\mathrm{C}$ genotype are associated with post-operative complication following coronary artery bypass graft (CABG) surgery. Atherosclerosis May 204(1), 196-201.

Sarecka B, Zak I, and Krauze J (2008). Synergistic effects of the polymorphisms in the $P A I-1$ and $I L-6$ genes with smoking in determining their associated risk with coronary artery disease. Clinical Biochemistry May 41(7-8), 467-473.

Sarecka-Hujar B, Zak I, and Krauze J (2008). Carrier-state of two or three polymorphic variants of MTHFR, IL-6 and ICAMI genes increases the risk of coronary artery disease. Kardiologia Polska Dec 66(12), 1269-1277.

Savva J, Maqbool A, White HL, Galloway SL, Yuldasheva NY, Ball SG, et al. (2009). Polymorphisms of adrenoceptors are not associated with an increased risk of adverse event in heart failure: a MERIT-HF substudy. Journal of Cardiac Failure Jun 15(5), $435-441$.

Schäuble N, Geller F, Siegfried W, Goldschmidt H, Remschmidt H, Hinney A, et al. (2003). No evidence for involvement of the promoter polymorphism -866 G/A of the UCP2 gene in childhood-onset obesity in humans. Experimental and Clinical Endocrinology \& Diabetes Apr 111(2), 73-76.

Schneider A, Tögel S, Barmada MM, and Whitcomb DC (2004). Genetic analysis of the glutathione s-transferase genes MGST1, GSTM3, GSTT1, and GSTM1 in patients with hereditary pancreatitis. Journal of Gastroenterology Aug 39(8), 783-787.

Seki N, Kamizono S, Yamada A, Higuchi T, Matsumoto H, Niiya F, et al. (1999). Polymorphisms in the 5-flanking region of S. Kamizono A. Yamada tumor necrosis 
factor-a gene in patients with T. Higuchi rheumatoid arthritis. Tissue Antigens Aug 54(2), 194-197.

Sekuri C, Cam FS, Sagcan A, Ercan E, Tengiz I, Alioglu E, et al. (2007). No association of interleukin-6 gene polymorphism $(-174 \mathrm{G} / \mathrm{C})$ with premature coronary artery disease in a Turkish cohort. Coronary Artery Disease Aug 18(5), 333-337.

Sertic J, Juricic L, Ljubic H, Bozina T, Lovric J, Markeljevic J, et al. (2009). Variants of ESR1, APOE, LPL and IL-6 loci in young healthy subjects: association with lipid status and obesity. BMC Research Notes Oct 5, 2, 203.

Setiawan VW, Zhang ZF, Yu GP, Li YL, Lu ML, Tsai CJ, et al. (2000). GSTT1 and GSTM1 Null Genotypes and the Risk of Gastric Cancer: A Case-Control Study in a Chinese Population. Cancer Epidemiology, Biomarkers \& Prevention Jan 9(1), 73-80.

Shaat N, Ekelund M, Lernmark A, Ivarsson S, Almgren P, Berntorp K, et al. (2005). Association of the E23K polymorphism in the $K C N J 11$ gene with gestational diabetes mellitus. Diabetologia Dec 48(12), 2544-2551.

Shin BS, Oh SY, Kim YS, and Kim KW. (2008). The paraoxonase gene polymorphism in stroke patients and lipid profile. Acta Neurologica Scandinavica Apr 117(4), 237-243.

Shioji K, Mannami T, Kokubo Y, Goto Y, Nonogi H, and Iwai N. (2004). An association analysis between ApoAl polymorphisms and the high-density lipoprotein (HDL) cholesterol level and myocardial infarction (MI) in Japanese. Journal of Human Genetics 49(8), 433-439.

Siitonen N, Lindström J, Eriksson J, Valle TT, Hämäläinen H, Ilanne-Parikka P, et al. (2004). Association between a deletion/insertion polymorphism in the $\alpha 2 \mathrm{~B}$-adrenergic receptor gene and insulin secretion and type 2 diabetes. The Finnish Diabetes Prevention Study. Diabetologia Aug 47(8), 1416-1424. 
Silver K, Mitchell BD, Walston J, Sorkin JD, Stern MP, Roth J, et al. (1997). TRP64ARG beta 3-adrenergic receptor and obesity in Mexican Americans. Human Genetics Dec 101(3), 306-311.

Simopoulos AP (2002). Genetic Variation and dietary response: Nutrigenetics/Nutrigenomics. Asia Pacific Journal of Clinical Nutrition 11(S6), S117S128.

Singh N, Sinha N, Kumar S, Pandey CM, and Agrawal S (2011). Glutathione STransferase Gene polymorphism as a susceptibility factor for acute myocardial infarction and smoking in the North Indian population. Cardiology 118(1), 16-21.

Skjelbred CF, Saebø M, Hjartåker A, Grotmol T, Hansteen IL, Tveit KM, et al. (2007). Meat, vegetables and genetic polymorphisms and the risk of colorectal carcinomas and adenomas. BMC Cancer Dec 19, 7, 228.

Slattery ML, Samowtiz W, Ma K, Murtaugh M, Sweeney C, Levin TR, et al. (2004). CYP1A1, cigarette smoking, and colon and rectal cancer. American Journal of Epidemiology Nov 1, 160(9), 842-852.

Smallwood L, Allcock R, van Bockxmeer F, Warrington N, Palmer LJ, Iacopetta B, et al. (2008). Polymorphisms of the interleukin-6 gene promoter and abdominal aortic aneurysm. European Journal of Vascular and Endovascular Surgery Jan 35(1), 31-36.

Snapir A, Heinonen P, Tuomainen TP, Alhopuro P, Karvonen MK, Lakka TA, et al. (2001). An Insertion/Deletion polymorphism in the a2B-adrenergic receptor gene is a novel genetic risk factor for acute coronary events. Journal of the American College of Cardiology May 37(6), 1516-1522.

Song KH, Yu SG, Cha S, and Kim JY (2012). Association of the Apolipoprotein A5 gene $-1131 \mathrm{~T}>\mathrm{C}$ polymorphism with serum lipids in Korean subjects: Impact of Sasang 
constitution. Evidence-Based Complementary and Alternative Medicine. 2012, 598394.

Srinivasan SR, Li S, Chen W, Tang R, Bond MG, Boerwinkle E, et al. (2004). Q192R polymorphism of the paraoxanase 1 gene and its association with serum lipoprotein variables and carotid artery intima-media thickness in young adults from a biracial community The Bogalusa Heart Study. Atherosclerosis Nov 177(1), 167-174.

Stancáková A, Baldaufová L, Javorský M, Kozárová M, Salagovic J, and Tkác I (2006). Effect of gene polymorphisms on lipoprotein levels in patients with dyslipidemia of metabolic syndrome. Physiological Research 55(5), 483-490.

Su SY, Chen JH, Huang JF, Wang XL, Zhao JG, Shen Y, et al. (2005). Paraoxonase gene cluster variations associated with coronary heart disease in Chinese Han women. Chinese Medical Journal 118(14), 1167-1174.

Suk Danik J, Chasman DI, Cannon CP, Miller DT, Zee RY, Kozlowski P, et al. (2006). Influence of genetic variation in the C-Reactive Protein gene on the inflammatory response during and after Acute coronary ischemia. Annals of Human Genetics Nov 70(Pt 6), 705-716.

Suk HJ, Ridker PM, Cook NR, and Zee RY, (2005). Relation of polymorphism within the C-reactive protein gene and plasma CRP levels. Atherosclerosis Jan 178(1), 139-145.

Sun H, Zhang D, and Zhao J (2008). The interleukin-6 gene $-572 \mathrm{G}>\mathrm{C}$ promoter polymorphism is related to intracranial aneurysms in Chinese Han nationality. Neuroscience Letters Jul 25, 440(1), 1-3.

Suzuki N, Matsunaga T, Nagasumi K, Yamamura T, Shihara N, Moritani T, et al. (2003). Alpha(2B)-adrenergic receptor deletion polymorphism associates with autonomic nervous system activity in young healthy Japanese. The Journal of Clinical Endocrinology and Metabolism Mar 88(3), 1184-1187. 
Sykiotis GP, Polyzogopoulou E, Georgopoulos NA, Trakada G, Spyropoulos K, Kalfarentzos F, et al. (2003). The a2b adrenergic receptor deletion/insertion polymorphism in morbid obesity. Clinical Autonomic Research Jun 13(3), 203-207.

Szalai AJ, Alarcón GS, Calvo-Alén J, Toloza SM, McCrory MA, Edberg JC, et al. (2005). Systemic lupus erythematosus in a multi-ethnic US Cohort (LUMINA). XXX: association between $\mathrm{C}$-reactive protein $(C R P)$ gene polymorphisms and vascular events. Rheumatology Jul 44(7), 864-868.

Szalai C, Keszei M, Duba J, Prohászk Z, Kozma GT, Császár A, et al. (2004). Polymorphism in the promoter region of the apolipoprotein $A 5$ gene is associated with an increased susceptibility for coronary artery disease. Atherosclerosis Mar 173(1), 109-114.

Takata M, Inazu A, Katsuda S, Miwa K, Kawashiri MA, Nohara A, et al. (2006). CETP (cholesteryl ester transfer protein) promoter $-1337 \mathrm{C}>\mathrm{T}$ polymorphism protects against coronary atherosclerosis in Japanese patients with heterozygous familial hypercholesterolaemia. Clinical Science Nov 111(5), 325-331.

Tamer L, Ateş NA, Ateş C, Ercan B, Elipek T, Yildirim H, et al. (2005). Glutathione Stransferase M1, T1 and P1 genetic polymorphisms, cigarette smoking and gastric cancer risk. Cell Biochemistry and Function Jul-Aug 23(4), 267-272.

Tekola Ayele F, Doumatey A, Huang H, Zhou J, Charles B, Erdos M, et al. (2012). Genome-wide associated loci influencing interleukin (IL)-10, IL-1Ra, and IL-6 levels in African Americans. Immunogenetics May 64(5), 351-359.

Terán-García M, Després JP, Tremblay A, and Bouchard C (2008). Effects of cholesterol ester transfer protein $(C E T P)$ gene on adiposity in response to long-term overfeeding. Atherosclerosis Jan 196(1), 455-460. 
Thalmaier D, Dambacher J, Seiderer J, Konrad A, Schachinger V, Pfennig S, et al (2006). The $+1059 \mathrm{G} / \mathrm{C}$ polymorphism in the $\mathrm{C}$-reactive protein $(C R P)$ gene is associated with involvement of the terminal ileum and decreased serum CRP levels in patients with Crohn's disease. Alimentary Pharmacology \& Therapeutics Oct 24 (7), 1105-1115.

Thibaudin D, Thibaudin L, Berthoux P, Mariat C, Filippis JP, Laurent B, et al. (2007). TNFA2 and $\mathrm{d} 2$ alleles of the tumor necrosis factor alpha gene polymorphism are associated with onset/ occurrence of idiopathic membranous nephropathy. Kidney International Mar 71(5), 431-437.

Thomas GN, Tomlinson B, Chan JC, Young RP, and Critchley JA (2000). The Trp64Arg polymorphism of the b3-adrenergic receptor gene and obesity in Chinese subjects with components of the metabolic syndrome. International Journal of Obesity May 24(5), $545-551$.

Thompson JF, Lira ME, Durham LK, Clark RW, Bamberger MJ, and Milos PM (2003). Polymorphisms in the CETP gene and association with CETP mass and HDL levels. Atherosclerosis Apr 167(2), 195-204.

Tischendorf JJ, Yagmur E, Scholten D, Vidacek D, Koch A, Winograd R, et al. (2007). The interleukin-6 (IL6)-174 G/C promoter genotype is associated with the presence of septic shock and the ex vivo secretion of IL6. International Journal of Immunogenetics Dec 34(6), 413-418.

Tong SY, Lee JM, Song ES, Lee KB, Kim MK, Yun YM, et al. (2010). The effects of polymorphisms in methylenetetrahydrofolate reductase (MTHFR), methionine synthase $(M T R)$, and methionine synthase reductase $(M T R R)$ on the risk of cervical intraepithelial neoplasia and cervical cancer in Korean women. Cancer Causes and Control Jan 21(1), 23-30. 
Tong Y, Wang Z, Geng Y, Liu J, Zhang R, Lin Q, et al. (2010). The association of functional polymorphisms of $I L-6$ gene promoter with ischemic stroke: Analysis in two Chinese populations. Biochemical and Biophysical Research Communications Jan $1,391(1), 481-485$.

Topol EJ, McCarthy J, Gabriel S, Moliterno DJ, Rogers WJ, Newby LK, et al. (2001). Single nucleotide polymorphisms in multiple novel thrombospondin genes may be associated with familial premature myocardial infarction. Circulation Nov 27, 104(22), 2641-2644.

Tsai CT, Hwang JJ, Lai LP, Wang YC, Lin JL, and Chiang FT (2009). Interaction of gender, hypertension, and the angiotensinogen gene haplotypes on the risk of coronary artery disease in a large angiographic cohort. Atherosclerosis Mar 203(1), 249-256.

Tsai MY, Bignell M, Yang F, Welge BG, Graham KJ, and Hanson NQ (2000). Polygenic influence on plasma homocysteine: association of two prevalent mutations, the 844ins68 of cystathionine beta-synthase and A(2756)G of methionine synthase, with lowered plasma homocysteine levels. Atherosclerosis Mar 149(1), 131-137.

Turner F, Smith G, Sachse C, Lightfoot T, Garner RC, Wolf CR, et al. (2004). Vegetable, fruit and meat consumption and potential risk modifying genes in relation to colorectal cancer. International Journal of Cancer Nov 1, 112(2), 259-264.

Ukkola O, Tremblay A, and Bouchard C (2001). Beta-2 adrenergic receptor variants are associated with subcutaneous fat accumulation in response to long-term overfeeding. International Journal of Obesity Nov 25(11), 1604-1608.

Ukkola O, Pérusse L, Chagnon YC, Després JP, and Bouchard C (2001). Interactions among the glucocorticoid receptor, lipoprotein lipase and adrenergic receptor genes and abdominal fat in the Quebec Family Study. International Journal of Obesity Sep 25(9), 1332-1339. 
Ukkola O, Rankinen T, Weisnagel SJ, Sun G, Pérusse L, Chagnon YC, et al. (2000). Interactions among the a2-, b2-, and b3-adrenergic receptor genes and obesity-related phenotypes in the Quebec Family Study. Metabolism Aug 49(8), 1063-1070.

Upadhyay R, Jain M, Kumar S, Ghoshal UC, and Mittal B (2008). Association of interleukin-6 $(-174 \mathrm{G}>\mathrm{C})$ promoter polymorphism with risk of squamous cell esophageal cancer and tumor location: An exploratory study. Clinical Immunology Aug 128(2), 199-204.

Vaisi-Raygani A, Rahimi Z, Tavilani H, Vaisi-Raygani H, Kiani A, Aminian M, et al. (2012). Synergism between paraoxonase Arg 192 and the angiotensin converting enzyme D allele is associated with severity of coronary artery disease. Molecular Biology Reports Mar 39(3), 2723-2731.

Valdivielso P, Ariza MJ, de la Vega-Román C, González-Alegre T, Rioja J, Ulzurrun E, et al. (2008). Association of the $-250 \mathrm{G} / \mathrm{A}$ promoter polymorphism of the hepatic lipase gene with the risk of peripheral arterial disease in type 2 diabetic patients. Journal of Diabetes and Its Complications Jul-Aug 22(4), 273-277.

Van Acker BA, Botmab GJ, Zwinderman AH, Kuivenhoven JA, Dallinga-Thie GM, Sijbrands EJ REGRESS Study Group, et al. (2008). High HDL cholesterol does not protect against coronary artery disease when associated with combined cholesteryl ester transfer protein and hepatic lipase gene variants. Atherosclerosis Sep 200(1), 161-167.

Van Himbergen TM, Roest M, De Graaf J, Jansen EH, Hattori H, Kastelei JJ, Voorbij HA, Stalenhoef AF, Van Tits LJ, et al. (2005). Indications that paraoxonase-1 contributes to plasma high density lipoprotein levels in familial hypercholesterolemia. The Journal of Lipid Research Mar 46(3), 445-451. 
Van Himbergen TM, Van Tits LJ, Ter Avest E, Roest M, Voorbij HA, De Graaf J, et al. (2008). Paraoxonase (PON1) is associated with familial combined hyperlipidemia. Atherosclerosis Jul 199(1), 87-94.

Van Venrooij FV, Stolk RP, Banga JD, Sijmonsma TP, van Tol A, Erkelens DW DALI Study Group, et al. (2003). Common cholesteryl ester transfer protein gene polymorphisms and the effect of atorvastatin therapy in type 2 diabetes. Diabetes Care Apr 26(4), 1216-1223.

Vasudevan R, Ismail P, Stanslas J, Shamsudin N, and Ali AB (2008). Association of Insertion/Deletion polymorphism of alpha-adrenoceptor gene in essential hypertension with or without type 2 diabetes mellitus in Malaysian subjects. International Journal of Biological Sciences 4(6), 362-367.

Veen G, Giltay EJ, van Vliet IM, Derijk RH, Klaassens ER, van Pelt J, et al. (2011). Creactive protein polymorphisms are associated with the cortisol awakening response in basal conditions in human subjects. Stress Mar 14(2), 128-135.

Vieira-Filho JP, Reis AF, Kasamatsu TS, Tavares EF, Franco LJ, Matioli SR, et al. (2004). Influence of the polymorphisms Tpr64Arg in the beta 3-adrenergic receptor gene and Pro12Ala in the PPAR gamma 2 gene on metabolic syndrome-related phenotypes in an indigenous population of the Brazilian Amazon.Diabetes Care Feb 27(2), 621-622.

Vimaleswaran KS, Radha V, Ghosh S, Majumder PP, Sathyanarayana Rao MR, and Mohan V (2011). Uncoupling protein 2 and 3 gene polymorphisms and their association with type 2 diabetes in Asian Indians. Diabetes Technology and Therapeutics Jan 13(1), 19-25.

Vogler S, Goedde R, Miterski B, Gold R, Kroner A, Koczan D, et al. (2005). Association of a common polymorphism in the promoter of $U C P 2$ with susceptibility to multiple sclerosis. Journal of Molecular Medicine Oct 83(10), 806-811. 
Von Wowern F, Bengtsson K, Lindblad U, Råstam L, and Melander O (2004). Functional variant in the (alpha)2B adrenoceptor gene, a positional candidate on chromosome 2 , associates with hypertension. Hypertension Mar 43(3), 592-597.

Wagner R, Dudziak K, Herzberg-Schäfer SA, Machicao F, Stefan N, Staiger H, et al. (2011). Glucose-raising genetic variants in MADD and ADCY5 impair conversion of proinsulin to insulin. PLoS ONE 6 (8), 23639.

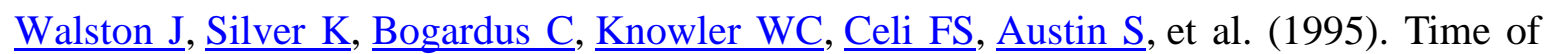
onset of non-insulin-dependent diabetes mellitus and genetic variation in the beta 3adrenergic-receptor gene. The New England Journal of Medicine Aug 10 333(6), 343 347.

Wang G, Zhang L, and Li Q (2006). Genetic polymorphisms of GSTT1, GSTM1, and NQO1 genes and diabetes mellitus risk in Chinese population. Biochemical and Biophysical Research Communications Mar 10, 341(2), 310-313.

Wang H, Zhou Y, Zhuang W, Yin YQ, Liu GJ, Wu TX, et al. (2010). Glutathione STransferase M1 Null genotype associated with gastric cancer among Asians. Digestive Diseases and Sciences Jul 55(7), 1824-1830.

Wang J, Qiang H, Chen D, Zhang C, and Zhuang Y (2002). CETP gene mutation (D442G) increases low-density lipoprotein particle size in patients with coronary heart disease. Clinica Chimica Acta Aug 322(1-2), 85-90.

Wang LS, Yan JJ, Tang NP, Zhu J, Wang YS, Wang QM, et al. (2011). A polymorphism in the visfatin gene promoter is related to decreased plasma levels of inflammatory markers in patients with coronary artery disease. Molecular Biology Reports Feb $38(2), 819-825$

Wang Q, Hunt SC, Xu Q, Chen YE, Province MA, Eckfeldt JH, et al.(2006). The polymorphisms of C-reactive protein gene modify the association between central 
obesity and lung function in taiwan asthmatics. American Journal of Physiology. Heart and Circulatory Physiology Dec 291(6), H2752-2757.

Wang TN, Wu CC, Huang MS, Wang CC, Huang CC, Wang TH, et al. (2011). The Polymorphisms of C-Reactive Protein gene modify the association between central obesity and lung function in Taiwan asthmatics. Scandinavian Journal of Immunology Nov 74(5), 482-488.

Wang Y, Luk AO, Ma RC, So WY, Tam CH, Ng MC, et al. (2010). Independent predictive roles of eotaxin Ala23Thr, paraoxonase 2 Ser311Cys and b3-adrenergic receptor Trp64Arg polymorphisms on cardiac disease in type 2 diabetes-an 8-year prospective cohort analysis of 1297 patients. Diabetic Medicine Apr 27(4), 376-383.

Weiner AS, Beresina OV, Voronina EN, Voropaeva EN, Boyarskih UA, Pospelova TI, et al. (2011). Polymorphisms in folate-metabolizing genes and risk of non-Hodgkin's lymphoma. Leukemia Research Apr, 35(4), 508-515.

Weiner AS, Boyarskikh UA, Voronina EN, Selezneva IA, Sinkina TV, Lazarev AF, et al. (2012). Polymorphisms in the folate-metabolizing genes $M T R, M T R R$, and $C B S$ and breast cancer risk. Cancer Epidemiology Apr 36(2), e95-e100.

Whiting BM, Anderson JL, Muhlestein JB, Horne BD, Bair TL, Pearson RR, et al. (2005). Intermountain Heart Collaborative Study Group. Candidate gene susceptibility variants predict intermediate end points but not angiographic coronary artery disease. American Heart Journal Aug 150(2), 243-250.

Wilk JB, Myers RH, Pankow JS, Hunt SC, Leppert MF, Freedman BI, et al. (2006). Adrenergic Receptor Polymorphisms Associated with Resting Heart Rate: The HyperGEN Study. Annals of Human Genetics Sep 70(Pt 5), 566-573. 
Xie HG, Kim RB, Stein CM, Gainer JV, Brown NJ, and Wood AJ (1999). AlphalAadrenergic receptor polymorphism: association with ethnicity but not essential hypertension. Pharmacogenetics Oct 9(5), 651-656.

Yamada Y, Ando F, and Shimokata H (2007). Association of candidate gene polymorphisms with bone mineral density in community-dwelling Japanese women and men. International Journal of Molecular Medicine May 19(5), 791-801.

Yamada Y, Matsuo H, Warita S, Watanabe S, Kato K, Oguri M, et al. (2007). Prediction of genetic risk for dyslipidemia. Genomics Nov 90(5), 551-558.

Yamaguchi S, Yamada Y, Matsuo H, Segawa T, Watanabe S, Kato K, et al. (2007). Gender differences in the association of gene polymorphisms with type 2 diabetes mellitus. International Journal of Molecular Medicine Apr 19(4), 631-637.

Yamamoto-Furusho JK, Uscanga LF, Vargas-Alarcón G, Rodríguez-Pérez JM, Zuñiga J, and Granados J (2004). Polymorphisms in the promoter region of tumor necrosis factor alpha (TNF- $a$ and the HLA-DRB1 locus in Mexican Mestizo patients with ulcerative colitis. Immunology Letters Aug 15, 95(1), 31-35.

Yanbaeva DG, Dentener MA, Spruit MA, Houwing-Duistermaat JJ, Kotz D, Passos VL, et al. (2009). IL6 and CRP haplotypes are associated with COPD risk and systemic inflammation: a case-control study, BMC Medical Genetics Mar 9, 10, 23.

Yeh CC, Hsieh LL, Tang R, Chang-Chieh CR, and Sung FC (2005). Vegetable/fruit, smoking, glutathione S-transferase polymorphisms and risk for colorectal cancer in Taiwan. World Journal of Gastroenterology Mar 14, 11(10), 1473-1480.

Yen JH, Chen CJ, Tsai WC, Lin CH, Ou TT, Lin SC, et al. (2002). Tumor necrosis factor microsatellite alleles in patients with rheumatoid arthritis in Taiwan. Immunology Letters May 1, 81(3), 177-182. 
Yilmaz H, lisbir T, Agachan B, and Karaali ZE (2005). Effects of cholesterol ester transfer protein Taq1B gene polymorphism on serum lipoprotein levels in Turkish coronary artery disease patients. Cell Biochemistry and Function 23 (1), 23-28.

Yin RX, Li YY, and Lai CQ (2011). Apolipoprotein A1/C3/A5 haplotypes and serum lipid levels. Lipids in Health and Disease Aug 19, 10, 140.

Yin RX, Wu DF, Miao L, Aung LH, Cao XL, Yan TT, et al. (2012). Several genetic polymorphisms interact with overweight/obesity to influence serum lipid levels. Cardiovascular Diabetology Oct 8, 11, 123.

Zambon CF, Basso D, Navaglia F, Belluco C, Falda A, Fogar P, et al. (2005). Pro- and anti-inflammatory cytokines gene polymorphisms and Helicobacter pylori infection: interactions influence outcome. Cytokine Feb 21, 29(4), 141-152.

Zammit S, Spurlock G, Williams H, Norton N, Williams N, O'Donovan MC, et al. (2007). Genotype effects of CHRNA7, CNR1 and COMT in schizophrenia: interactions with tobacco and cannabis use. The British Journal of Psychiatry: The Journal of Mental Science. Nov 191, 402-407.

Zee RY, Hegener HH, Cook NR, and Ridker PM (2004). C-reactive protein gene polymorphisms and the risk of venous thromboembolism: a haplotype-based analysis. Thrombosis and Haemostasis Aug 2(8), 1240-1243.

Zee RY, Hegener HH, Fernandez-Cruz A, and Lindpaintner K (2004). C-reactive protein gene polymorphisms and the incidence of post-angioplasty restenosis. Atherosclerosis Oct 176(2), 393-396.

Zendehdel K, Bahmanyar S, McCarthy S, Nyren O, Andersson B, and Ye W (2009). Genetic polymorphisms of glutathione S-transferase genes GSTP1, GSTM1, and GSTT1 and risk of esophageal and gastric cardia cancers. Cancer Causes and Control Dec 20(10), 2031-2038. 
Zhang C, Lopez-Ridaura R, Rimm EB, Rifai N, Hunter DJ, and Hu FB (2005). Interactions between the $-514 \mathrm{C}>\mathrm{T}$ polymorphism of the hepatic lipase gene and lifestyle factors in relation to HDL concentrations among US diabetic men. The American Journal of Clinical Nutrition Jun 81(6), 1429-1435.

Zhang H, Ahmadi A, Arbman G, Zdolsek J, Carstensen J, Nordenskjöld B, et al. (1999). Glutathione S-Transferase T1 and M1 genotypes in normal mucosa, transitional mucosa and colorectal adenocarcinoma. International Journal of Cancer Apr 20, 84(2), 135-138.

Zhang LX, Sun Y, Liang Y, Li K, Chen Y, Gusanglamu, et al. (2012). Relationship between dyslipidemia and gene polymorphism in Tibetan population. Biomedical and Environmental Sciences Jun 25(3), 305-310.

Zhang X, Qi Q, Bray GA, Hu FB, Sacks FM, and Qi L (2012). APOA5 genotype modulates 2-y changes in lipid profile in response to weight-loss diet intervention: the Pounds Lost Trial. The American Journal of Clinical Nutrition Oct 96(4), 917-922.

Zhang Y, Wat N, Stratton IM, Warren-Perry MG, Orho M, Groop L, et al.(1996). UKPDS 19: heterogeneity in NIDDM: separate contributions of IRS-1 and beta 3-adrenergicreceptor mutations to insulin resistance and obesity respectively with no evidence for glycogen synthase gene mutations. UK Prospective Diabetes Study. Diabetologia Dec 39(12), 1505-1511.

Zheng K, Zhang S, Zhang L, He Y, Liao L, Hou Y, et al. (2005). Carriers of three polymorphisms of cholesteryl ester transfer protein gene are at increased risk to coronary heart disease in a Chinese population. International Journal of Cardiology 103 (3), 259- 265. 
Zhu LY, Hu LY, Li XL, Wang GY, Shan W, Ma LC, et al. (2010). Relationship between Trp64Arg mutation in the $\beta 3$-adrenergic receptor gene and metabolic syndrome: a seven-year follow-up study. Chinese Medical Journal Sep 123(17), 2375-2378.

\section{Websites}

http://ghr.nlm.nih.gov/handbook/testing/genetictesting. 
Supplementary figures 


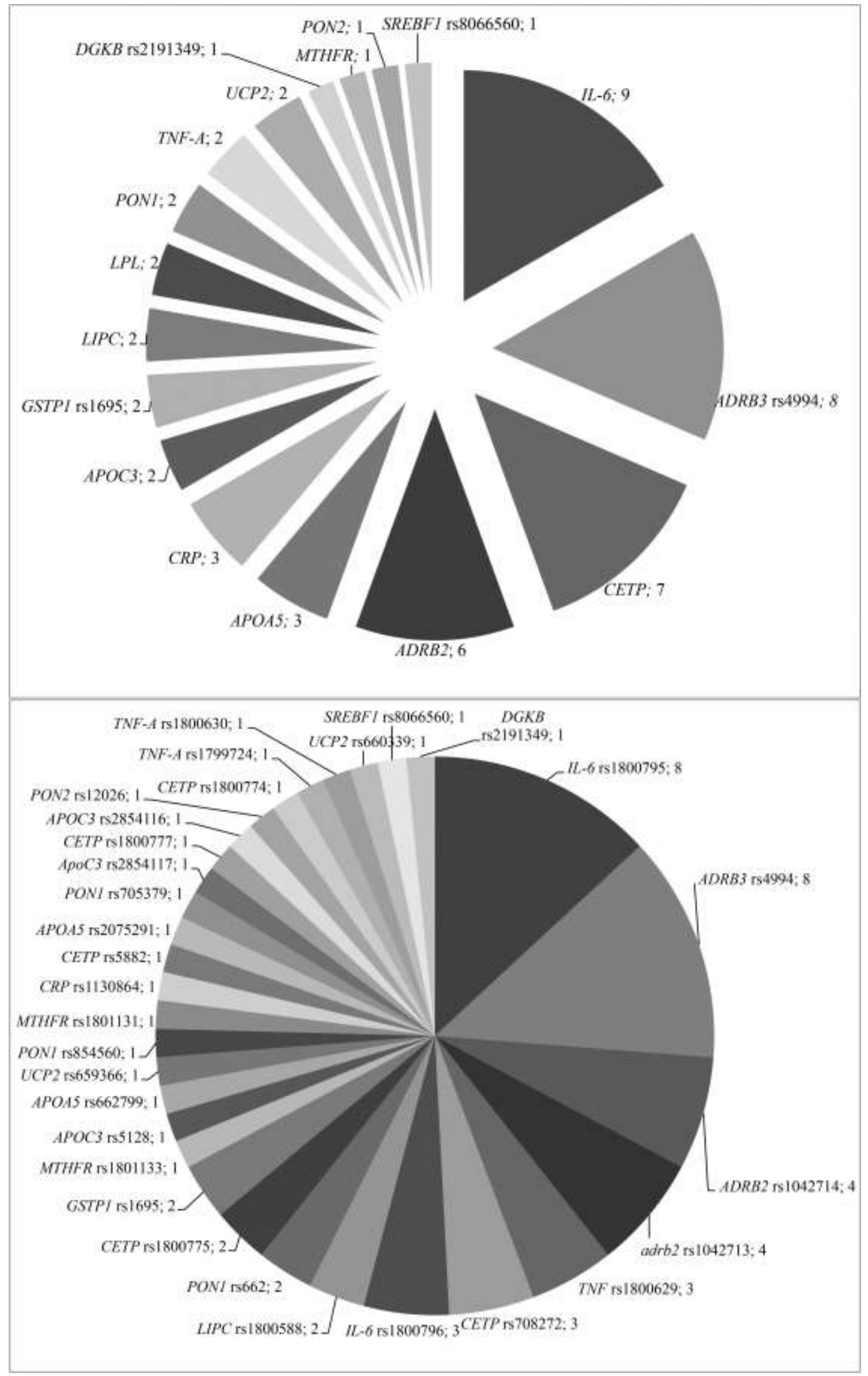




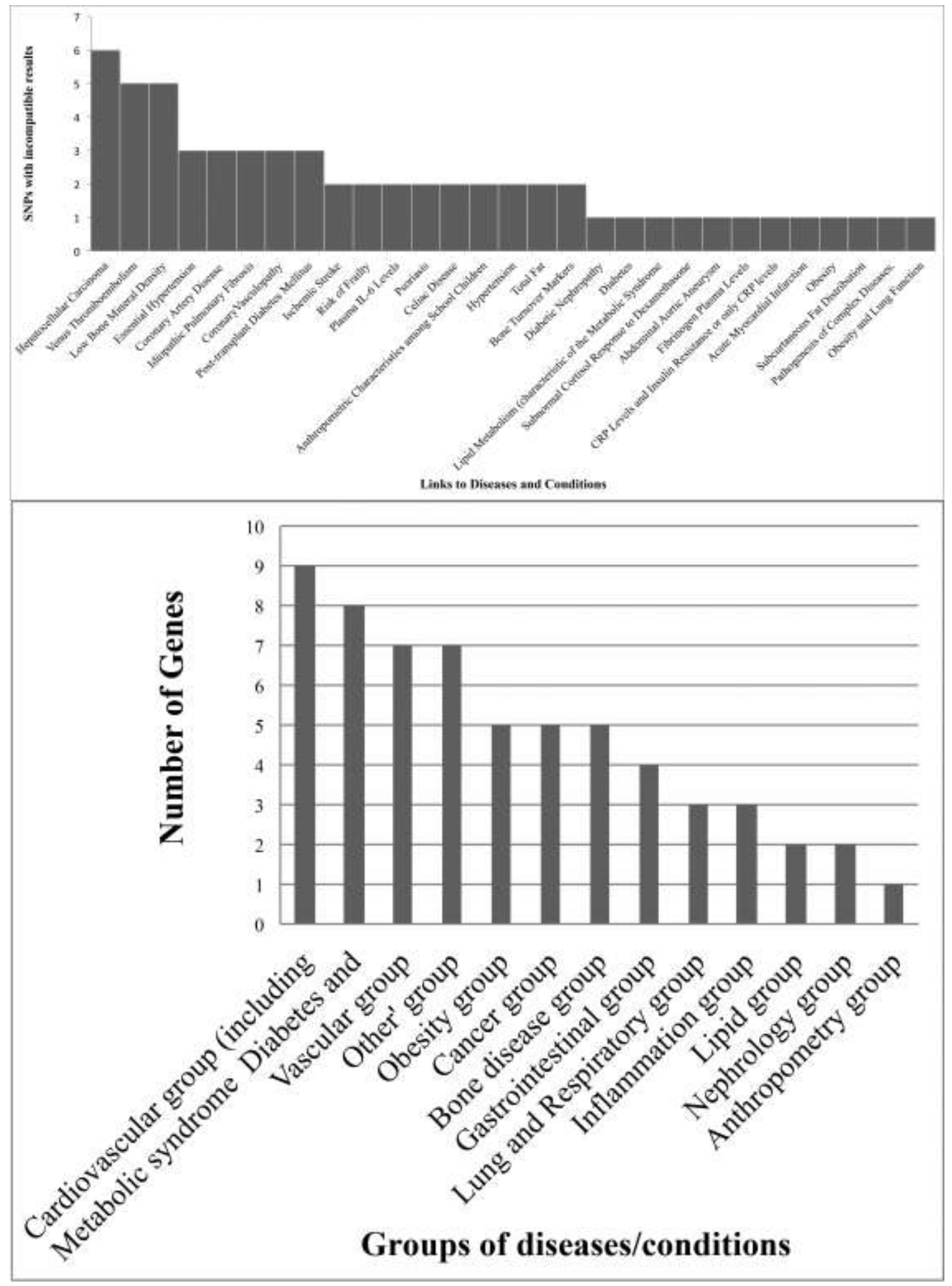




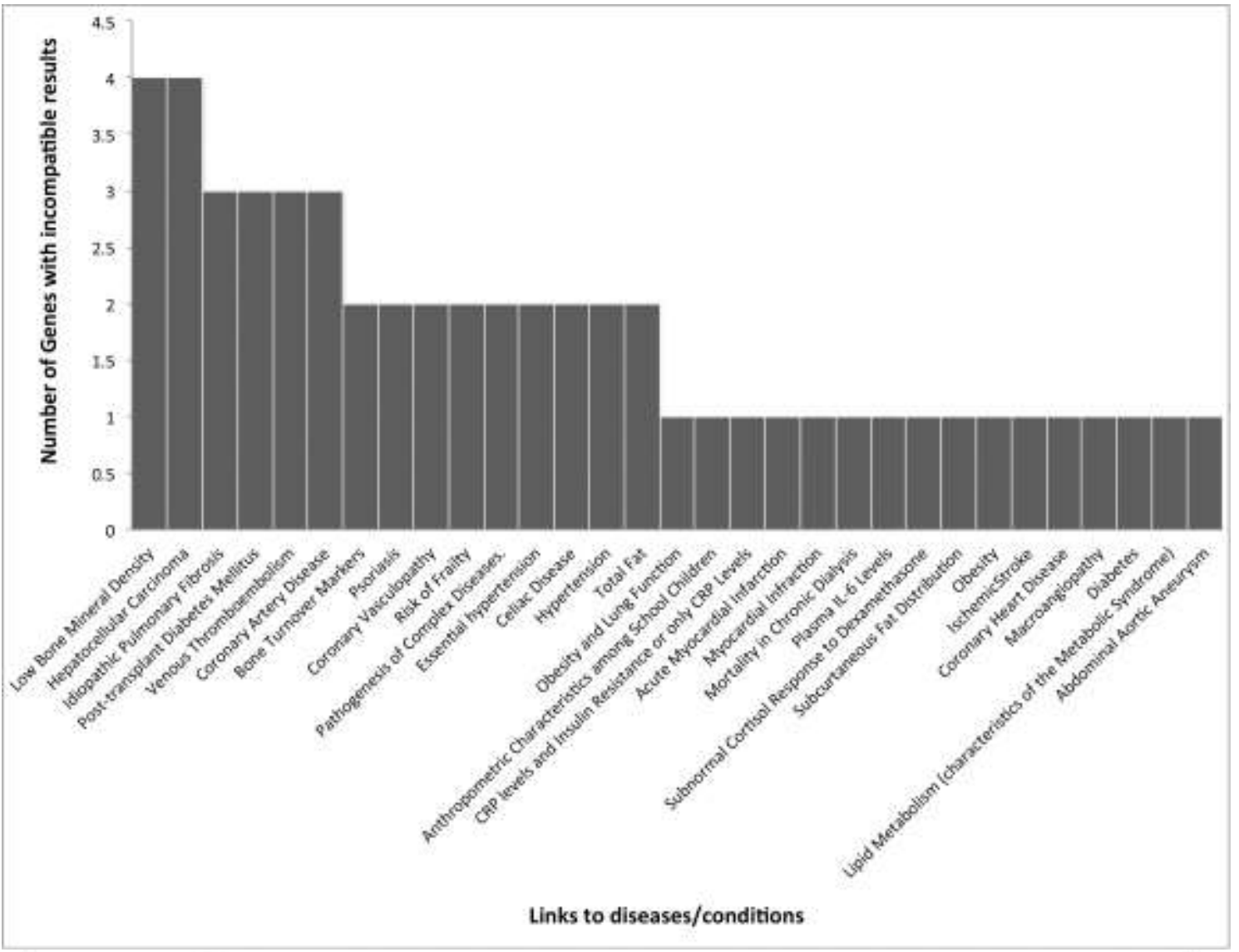

\begin{tabular}{|c|c|c|c|c|c|c|c|c|c|c|c|c|c|c|c|c|}
\hline Group: & 1 & 2 & 3 & 4 & 5 & 6 & 7 & 8 & 9 & 10 & 11 & 12 & 13 & 15 & 16 & 17 \\
\hline rs4704209 & & & & & & & & & & & & & & & & \\
\hline rs3761739 & & & & & & & & & & & & & & & & \\
\hline rs5909 & & & & & & & & & & & & & & & & \\
\hline rs3761738 & & & & & & & & & & & & & & & & \\
\hline rs17238540 & & & & & & & & & & & & & & & & \\
\hline rs10038095 & & & & & & & & & & & & & & & & \\
\hline rs3846663 & & & & & & & & & & & & & & & & \\
\hline rs2303152 & & & & & & & & & & & & & & & & \\
\hline rs6413503 & & & & & & & & & & & & & & & & \\
\hline rs440446 & & & & & & & & & & & & & & & & \\
\hline
\end{tabular}




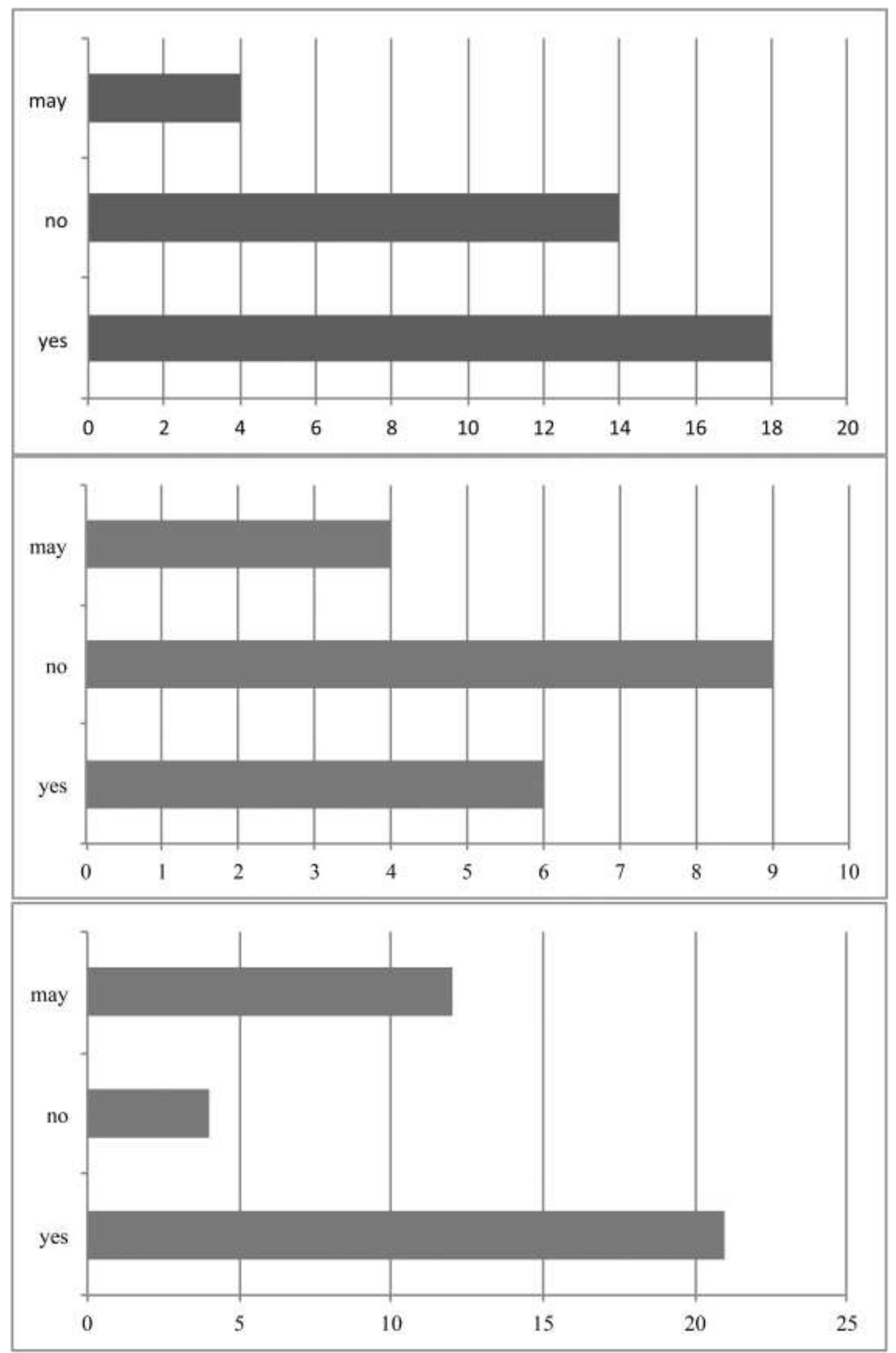




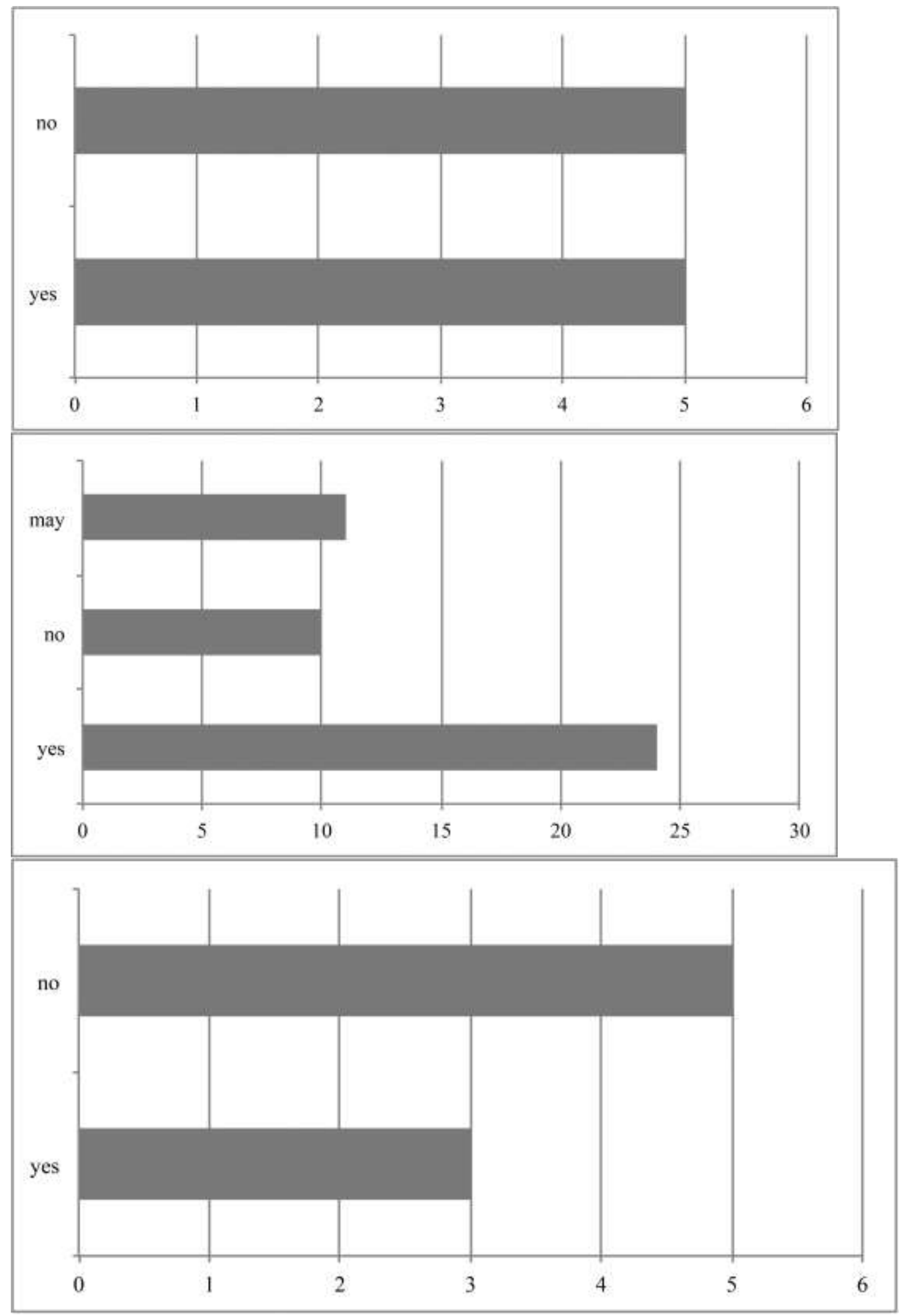



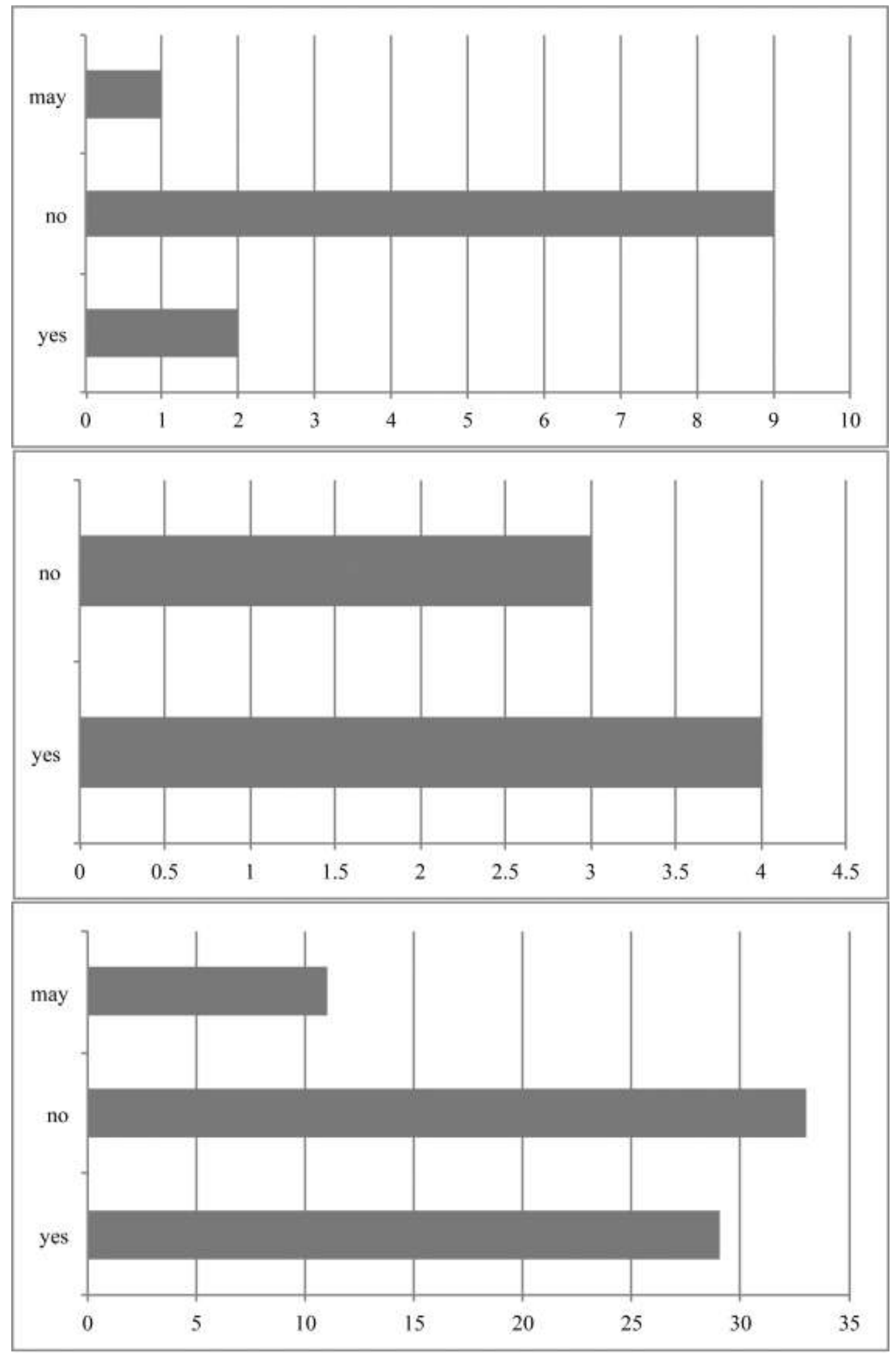


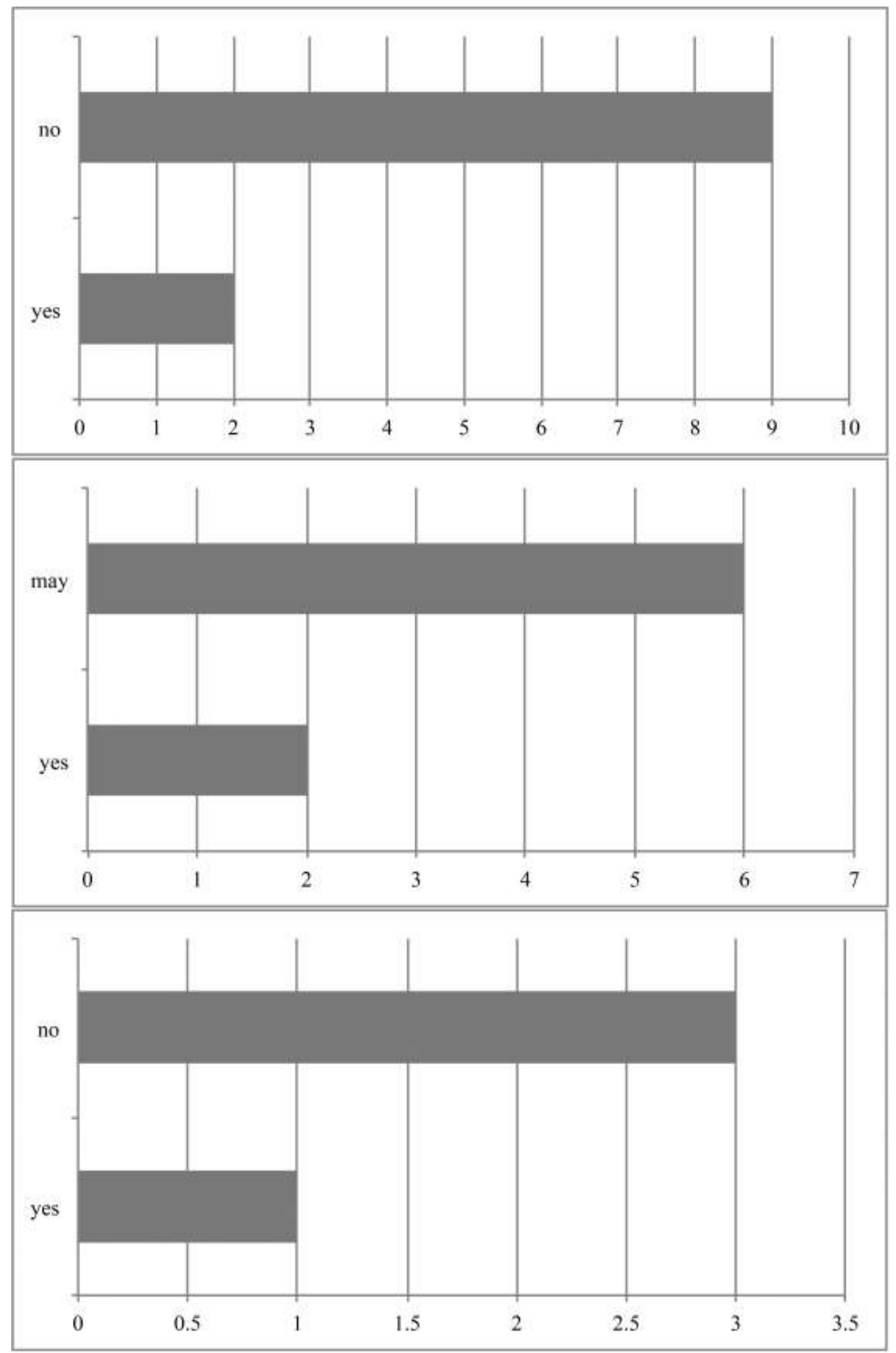




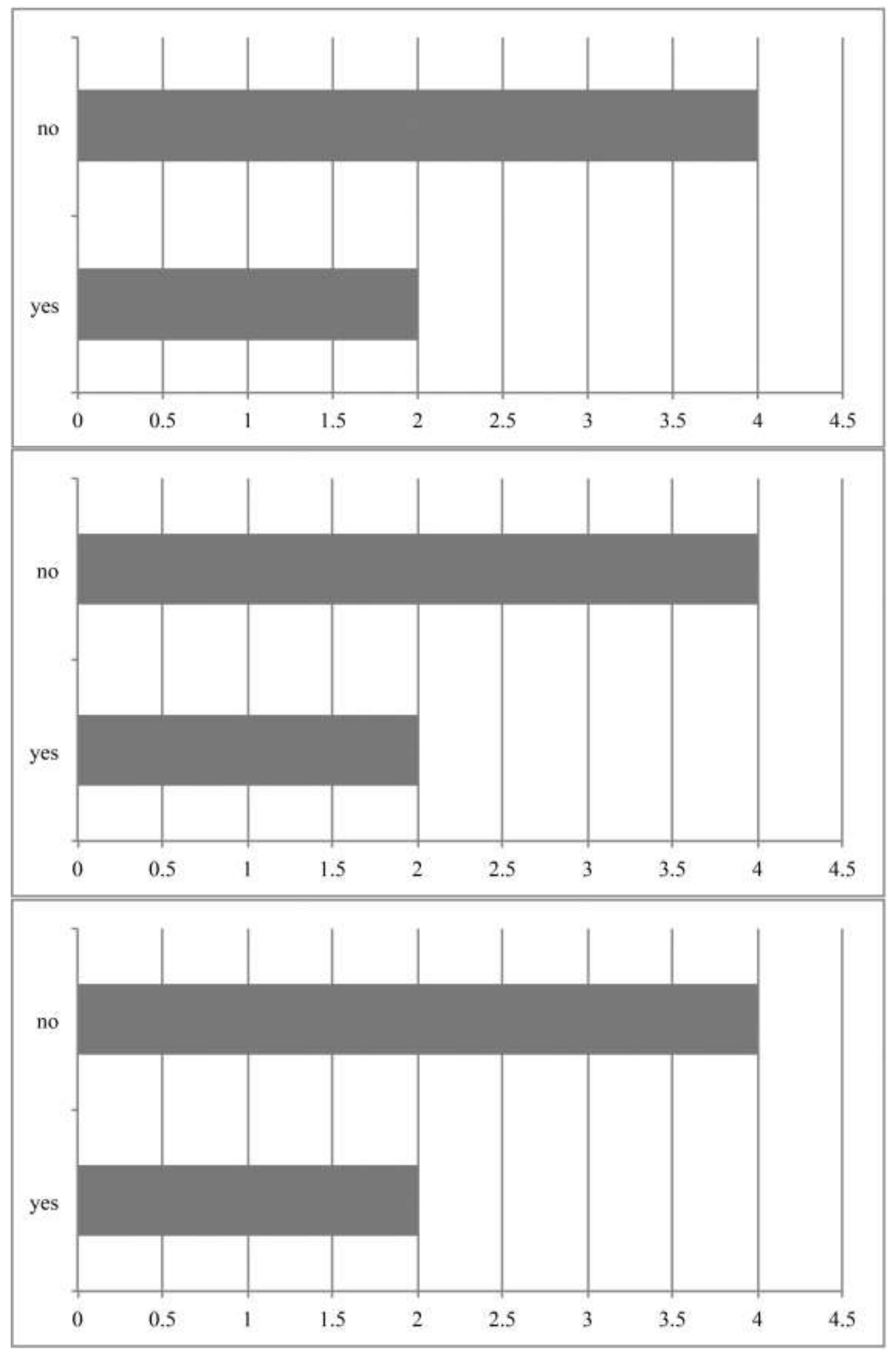

